University of Wollongong

Research Online

Faculty of Engineering - Papers (Archive)

Faculty of Engineering and Information

Sciences

$1-1-2005$

\title{
Predictions and observations of soft clay foundations stabilized with geosynthetic drains and vacuum surcharge
}

\author{
Buddhima Indraratna \\ University of Wollongong, indra@uow.edu.au \\ Cholachat Rujikiatkamjorn \\ University of Wollongong, cholacha@uow.edu.au
}

A. S. Balasubramaniam

Griffith University

V. Wijeyakulasuriya

Department of Main Roads, Queensland

Follow this and additional works at: https://ro.uow.edu.au/engpapers

Part of the Engineering Commons

https://ro.uow.edu.au/engpapers/191

\section{Recommended Citation}

Indraratna, Buddhima; Rujikiatkamjorn, Cholachat; Balasubramaniam, A. S.; and Wijeyakulasuriya, V.:

Predictions and observations of soft clay foundations stabilized with geosynthetic drains and vacuum surcharge 2005.

https://ro.uow.edu.au/engpapers/191

Research Online is the open access institutional repository for the University of Wollongong. For further information contact the UOW Library: research-pubs@uow.edu.au 


\title{
Chapter 7
}

\section{Predictions and Observations of Soft Clay Foundations Stabilized with Geosynthetic Drains and Vacuum Surcharge}

\author{
Buddhima Indraratna1, Cholachat Rujikiatkamjorn', \\ A. S. Balasubramaniam ${ }^{2}$ and Vasantha Wijeyakulasuriya ${ }^{3}$ \\ ${ }^{1}$ School of Civil Engineering, University of Wollongong, NSW 2522, Australia \\ ${ }^{2}$ School of Engineering, Griffiths University, Gold Coast, QLD 4111, Australia \\ ${ }^{3}$ Queensland Dept. of Main Roads, Brisbane, Australia
}

\begin{abstract}
This chapter starts with an introduction of a revised analytical model of radial drainage with vacuum preloading in both axisymmetric and plane strain conditions. Observed from large-scale radial drainage consolidation tests, the influence of vacuum pressure distribution along the drain length is examined through the dissipation of average excess pore pressure and associated settlement. The details of an appropriate conversion procedure by transforming permeability and vacuum pressure between axisymmetric and equivalent plane strain conditions are described through analytical and numerical schemes. The effects of the magnitude and distribution of vacuum pressure on soft clay consolidation are investigated on the basis of average excess pore pressure, consolidation settlement, and time analyses. The writers describe a multi-drain plane strain finite element method analysis based on permeability conversion, which is employed to study the behavior of embankments stabilized at the site of the Second Bangkok International Airport with vacuum-assisted prefabricated vertical drains. In the field, a constant suction head is not always stable because of the occurrence of air leaks; therefore the magnitude of applied vacuum pressure was adjusted accordingly. The theoretical (numerical) predictions are compared with measured field data such as settlements, excess pore pressures, and lateral movements. The case history analysis employing the writers' model indicates improved accuracy of the predictions in relation to the field observations. The data indicate that the efficiency of the prefabricated vertical drains depends on the magnitude and distribution of vacuum pressure as well as on the extent of air leak protection provided in practice.
\end{abstract}




\section{INTRODUCTION}

In recent years, the urgent need for construction of various infrastucture over unsuitable soft soil deposits has advanced soil improvement techniques. To avoid excessive settlement of highly compressible soil after construction, preloading prior to construction is considered to be one of the most practical methods; preloading being the application of surface, or vacuum loading, or groundwater lowering to attain the expected consolidation settlement under permanent load. However, for thick soil deposits with low permeability, the required consolidation time by preloading alone can be too long and bearing failure may take place during rapid embankment construction. Therefore, a system of vertical drains with preloading is frequently introduced to accelerate the consolidation process by shortening the drainage path from vertical to horizontal (Nicholson and Jardine, 1982). The performance of different types of vertical drains including sand drains, sand compaction piles, prefabricated vertical drains (PVDs, geosynthetic) and gravel piles have been studied in the past (Richart, 1957; Cooper and Rose, 1999; Indraratna et al., 1999; Indraratna and Sathananthan, 2003). The utilization of geosynthetic PVDs has become an economical and viable option because of their rapid installation with simple field equipment (Holtz et al., 1991; Shang et al., 1998). Due to the scarcity of suitable surcharge material and the relatively low cost of electrical power in certain areas, vacuum-assisted preloading with the vertical drain system has been used to achieve rapid consolidation and reduce the height of surchage fill (Kjellman, 1952; Qian et al., 1992; Chu et al., 2000; Eriksson et al., 2000; Gao, 2004). Furthermore, the advancement of airtight systems for vacuum application by synthetic covers has made this form of soil improvement even more attractive and viable.

In order to analyse the performance of vertical drains, unit cell theory representing a single drain surrounded by a soil annulus in axisymmetric condition (3D) was proposed by Barron (1948) and Richart (1957). Subsequently, Hird et al. (1992) and Indraratna and Redana (1997) proposed a unit cell formulated for the plane strain condition (2-D), which can be more suitably used in numerical modeling. For multi-drain simulation, a simplified plane strain (2-D) finite element analysis can be readily adapted to most field situations because it is almost impossible to conduct an analysis (even with the most powerful computers) employing an individual axisymmetric zone around each and every independent vertical drain, when there are hundreds of wick drains installed in large construction projects (Hansbo, 1981; Hansbo, 1997; Indraratna and Redana, 2000). To obtain realistic field predictions, the axisymmetric properties such as the permeability coefficients and drain geometry have to be converted into an equivalent 2-D plane strain condition, (Indraratna and Redana, 1997). The plane strain analysis can also take vacuum preloading into account in conjunction with PVD (e.g. Gabr and Szabo, 1997). Mohamedelhassan and Shang (2002) discussed the application of vacuum pressure and its benefits, but without the use of any vertical drains. The simulation of vacuum pressure with PVD in analytical or numerical models requires further refinement to obtain better field predictions. 
The main objective of this chapter is to present some comprehensive analytical solutions for vacuum preloading in conjunction with vertical drains, covering both the axisymmetric and equivalent plane strain conditions. The analytical predictions are compared to numerical results based on the finite element method using ABAQUS software, Version 6.4. Based on the equivalent plane strain solution, the numerical predictions are also compared to the field data (e.g. settlements, lateral displacements, and excess pore pressures).

\section{THEORETICAL BACKGROUND}

\subsection{Principles of vertical drain incorporating vacuum preloading}

The vacuum preloading method was initially introduced in Sweden by Kjellman (1952) for cardboard wick drains. It has been used extensively to accelerate the consolidation process for improving soft ground, such as Philadelphia International Airport, USA and Tianjin port, China (Holtan, 1965; Yan and Chu, 2003). Recently, the PVD system has also been employed to distribute vacuum pressure to deep subsoil layer and thereby increase the consolidation rate (e.g. Chu et al., 2000). Figure 1 shows the consolidation process of conventional method and vacuum-assisted preloading. The increase in the effective stress in soil mass for this method is attributed to the vacuum application in lieu of conventional surcharge. The characteristics of vacuum preloading in comparison with conventional preloading are as follows (Qian et al., 1992):

(a) The effective stress related to suction pressure increases equiaxially, and the corresponding lateral movement is compressive. Consequently, the risk of shear failure can be minimized even at a higher rate of embankment construction.

(b) The vacuum head can be distributed to a greater depth of the subsoil using the PVD system (Figure 2).

(c) The extent of surcharge fill can be decreased to achieve the same degree of consolidation, depending on the efficiency of the vacuum system in the field (i.e., air leaks).

(d) Since the surcharge height can be reduced, the maximum excess pore pressure generated by vacuum preloading is less than by the conventional surcharge method (Figure 1).

(e) With vacuum pressure, the inevitable unsaturated condition at the soil-drain interface may be improved, resulting in an increased rate of consolidation.

Yan and Chu (2003) stated that the cost of soil improvement by vacuum preloading reduces approximately $30 \%$ of that by conventional surcharge alone. The effectiveness of this system depends on: (a) integrity (airtight) of membrane, (b) effectiveness of the seal between the membrane edges and the ground surface, and (c) soil conditions and the location of ground water level (Cognon et al., 1994). Recently, Indraratna et al. (2004) showed by laboratory measurement that the distribution pattern of vacuum pressure along the PVDs may influence the overall performance of vacuum preloading system (Figure 2). 

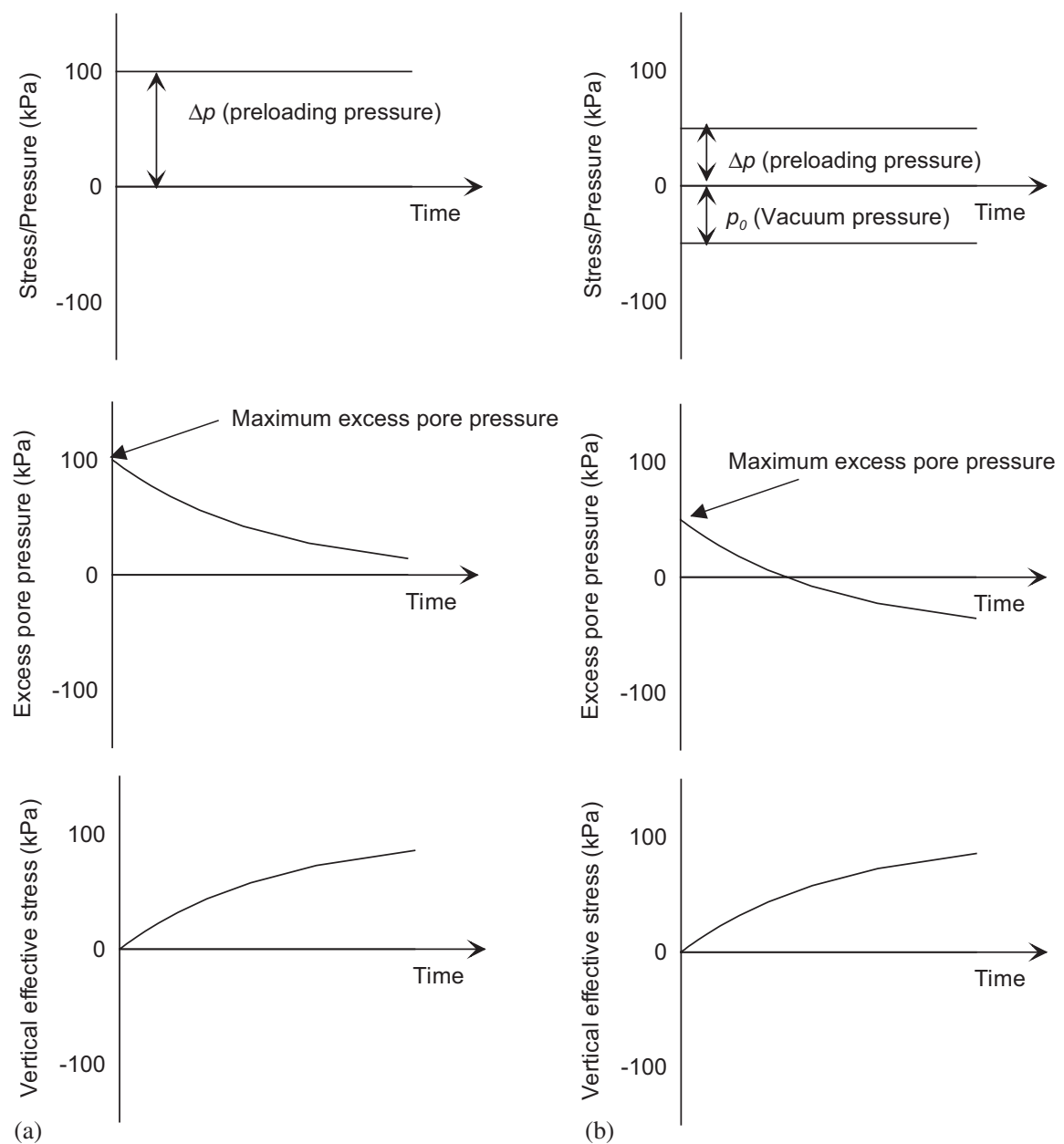

Figure 1. Consolidation process: (a) conventional loading, (b) vacuum preloading assuming no vacuum loss.

Figure 3 shows a typical a vacuum preloading layout incorporating a PVD arrangement (Indraratna et al., 2003). For a PVD system incorporating vacuum preloading, the installation of some horizontal drains in the transverse and longitudinal directions is usually required after installing the sand blanket. Subsequently, these drains can be connected to the edge of a peripheral Bentonite slurry trench, which is typically sealed by an impervious geomembrane. The trenches can then be filled with water to improve sealing between the membrane and the Bentonite slurry. The vacuum pumps are connected to the prefabricated discharge system extending from the trenches, and the suction head generated by the pump accelerates dissipation of excess pore water pressure in the soil toward the drains and the surface. 


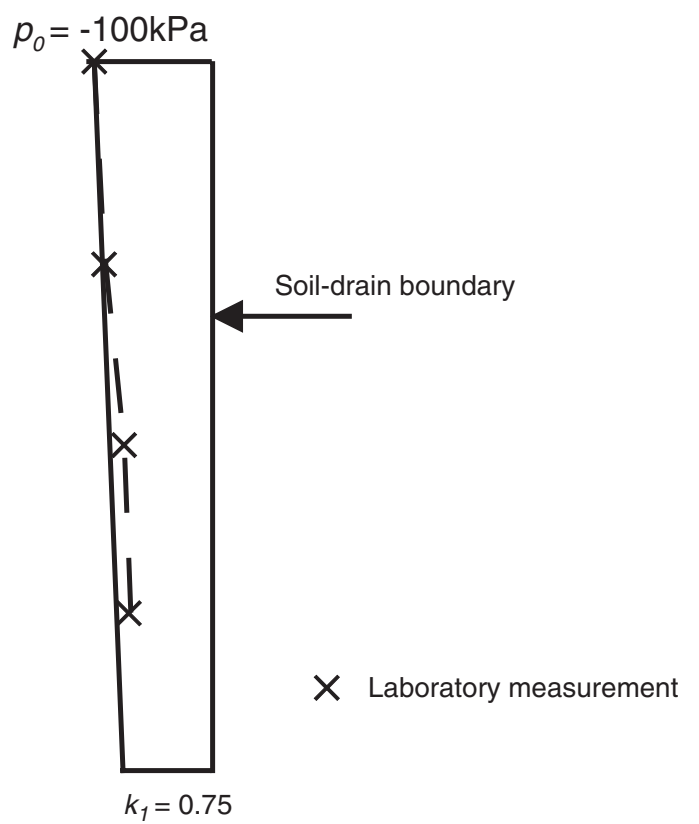

Figure 2. Measured pore water pressure along the drain boundary at $100 \mathrm{kPa}$ suction (inspired by Indraratna, et al., 2004.)

\subsection{Revised theory of consolidation incorporating radial drainage subjected to vacuum preloading}

2.2.1. Solution for axisymmetric condition. Barron (1948) presented an original solution to the problem of radial consolidation by drain wells. Two distinctly different cases, considering both smear and well-resistance effects, namely, (a) free strain and (b) equal strain were comprehensively analyzed. Various solutions incorporating different assumptions and boundary conditions were later given by Yoshikuni and Nakanodo (1974), Hansbo (1979), Onoue (1988) and Holtz et al. (1991). Barron (1948) showed that the average consolidation obtained in both "free strain" and "equal strain" cases are nearly the same. Moreover, the solution obtained from the "equal strain" assumption was simpler than that obtained from the "free strain." It is also noted that a uniform settlement over a circular zone of influence for each vertical drain is evident in the field, and therefore, "equal strain" is now commonly treated in most radial drainage-consolidation analyses.

When vacuum pressure is applied in the field through PVDs, the suction head may decrease with depth, thereby reducing efficiency (Figure 4). In order to study the effect of vacuum loss, a trapezoidal vacuum pressure distribution is conveniently assumed. In the vertical direction (along the drain boundary), the vacuum pressure is assumed to vary from $-p_{0}$ to $-k_{1} p_{0}$. 


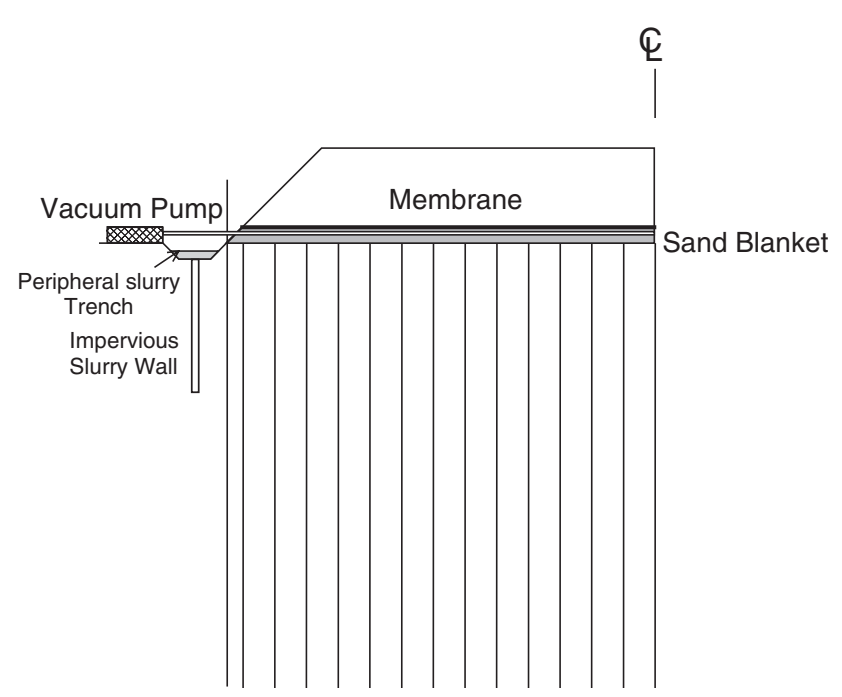

Figure 3. Schematic diagram of PVDs incorporating preloading system.

Based on the assumption given above, Indraratna et al. (2005) proposed comprehensive analytical solutions for vacuum preloading in conjunction with PVD. The average excess pore pressure ratio $\left(R_{u}=\Delta p / \bar{u}_{0}\right)$ of a soil cylinder for radial drainage incorporating vacuum preloading can be given by

$$
R_{u}=\left(1+\frac{p_{0}}{\bar{u}_{0}} \frac{\left(1+k_{1}\right)}{2}\right) \exp \left(-\frac{8 T_{\mathrm{h}}}{\mu}\right)-\frac{p_{0}}{\bar{u}_{0}} \frac{\left(1+k_{1}\right)}{2}
$$

and

$$
\mu=\ln \left(\frac{n}{s}\right)+\left(\frac{k_{\mathrm{h}}}{k_{\mathrm{s}}}\right) \ln (s)-0.75+\pi z(2 l-z) \frac{k_{\mathrm{h}}}{q_{\mathrm{w}}}\left\{1-\frac{k_{\mathrm{h}} / k_{\mathrm{s}}-1}{\left(k_{\mathrm{h}} / k_{\mathrm{s}}\right)(n / s)^{2}}\right\}
$$

where $p_{0}$ is the applied vacuum pressure at the top of the drain, $k_{1}$ the ratio between vacuum pressure at the bottom of the drain and vacuum pressure at the top of the drain, vacuum pressure ratio $(\mathrm{VPR})=p_{0} / \bar{u}_{0}$, with $\bar{u}_{0}$ the initial excess pore water pressure, $k_{\mathrm{h}}$ the horizontal permeability coefficient of soil in the undisturbed zone, $k_{\mathrm{s}}$ the horizontal permeability coefficient of soil in the smear zone, $T_{\mathrm{h}}$ the time factor, $n=$ ratio $d_{\mathrm{e}} / d_{\mathrm{w}}\left(d_{\mathrm{e}}\right.$ the diameter of equivalent soil cylinder $\left(=2 r_{\mathrm{e}}\right)$ and $d_{\mathrm{w}}$ the diameter of drain $\left.\left(=2 r_{\mathrm{w}}\right)\right), s=$ ratio $d_{\mathrm{s}} / d_{\mathrm{w}}\left(d_{\mathrm{s}}\right.$ the diameter of smear zone $=2 r_{\mathrm{s}}$ ), $z$ the depth, $l$ the equivalent length of drain, $q_{\mathrm{w}}$ the well discharge capacity.

A simplified form of $\mu$ can be alternatively given by

$$
\mu=\ln \left(\frac{n}{s}\right)+\left(\frac{k_{\mathrm{h}}}{k_{\mathrm{s}}}\right) \ln (s)-0.75+\pi z(2 l-z) \frac{k_{\mathrm{h}}}{q_{\mathrm{w}}}
$$



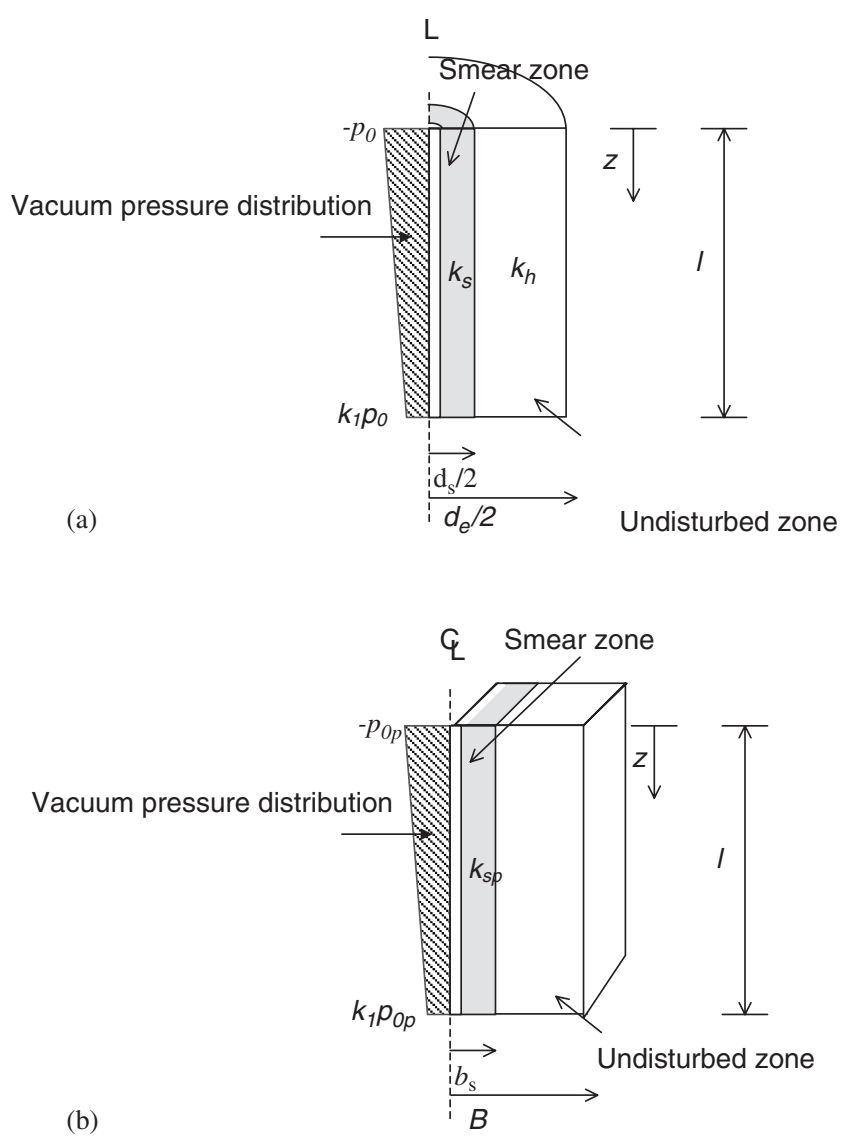

Figure 4. A unit cell with vacuum pressure distribution: (a) axisymmetric condition and (b) plane strain condition.

Considering only the effect of smear, Eq. (3) becomes

$$
\mu=\ln \left(\frac{n}{s}\right)+\left(\frac{k_{\mathrm{h}}}{k_{\mathrm{s}}}\right) \ln (s)-0.75
$$

Considering the well resistance only, Eq. (3) becomes

$$
\mu \approx \ln (n)-0.75+\pi z(2 l-z) \frac{k_{\mathrm{h}}}{q_{\mathrm{w}}}
$$

For an ideal drain, both smear and well resistance are ignored, hence, the above equation simplifies to

$$
\mu=\ln (n)-0.75
$$


Note that by substituting $p_{0}=0$ into Eq. (3), the original solution of Hansbo (1981) can be obtained.

2.2.2. Solution for plane strain condition. The vacuum pressure distribution with a plane strain unit cell in compliance with the axisymmetric condition is shown in Figure $4 \mathrm{~b}$. The average excess pore pressure ratio $\left(R_{u}=\Delta p / \bar{u}_{0}\right)$ for plane strain condition is repeated by (Indraratna et al., 2005)

$$
R_{\text {up }}=\left(1+\frac{p_{0 \mathrm{p}}}{\bar{u}_{0}} \frac{\left(1+k_{1}\right)}{2}\right) \exp \left(-\frac{8 T_{\mathrm{hp}}}{\mu_{\mathrm{p}}}\right)-\frac{p_{0 \mathrm{p}}}{\bar{u}_{0}} \frac{\left(1+k_{1}\right)}{2}
$$

and

$$
\begin{gathered}
\mu_{\mathrm{p}}=\alpha+\frac{k_{\mathrm{hp}}}{k_{\mathrm{sp}}}(\beta)+(\theta)\left(2 l z-z^{2}\right) \\
\alpha=\frac{2}{3} \frac{(n-s)^{3}}{n^{2}(n-1)} \\
\beta=\frac{2(s-1)}{n^{2}(n-1)}\left[n(n-s-1)+\frac{1}{3}\left(s^{2}+\mathrm{s}+1\right)\right] \\
\theta=\frac{2 k_{\mathrm{hp}}}{B q_{\mathrm{z}}}\left(1-\frac{1}{n}\right)
\end{gathered}
$$

Considering only the well resistance, Eq. (8) becomes

$$
\mu_{\mathrm{p}}=0.67+(\theta)\left(2 l z-z^{2}\right)
$$

Neglecting the effect of well resistance, Eq. (8) becomes

$$
\mu_{\mathrm{p}}=\alpha+\frac{k_{\mathrm{hp}}}{k_{\mathrm{sp}}}(\beta)
$$

For an ideal drain (both smear and well resistance are ignored), the above parameter becomes

$$
\mu_{\mathrm{p}}=0.67
$$

Note that by substituting $p_{0 \mathrm{p}}=0$ into Eq. (7), the solution proposed by Indraratna and Redana (2000) can be readily derived.

2.2.3. Equivalent plane strain condition procedure. It is almost impractical to conduct an analysis (even with the most powerful computers), employing an individual axisymmetric 
zone around every drain when there are hundreds of vertical drains installed in large ground improvement projects. Therefore, two-dimensional (2D) plane strain conversion is most convenient in terms of computational effectiveness compared to an extensive 3-D analysis that can lead to considerably more time required for convergence, even with a smaller number of drains. Complex mesh descretization often leads to poor convergence. Therefore, a simplified procedure for vertical drain modeling transforms relevent parameters from the true axisymmetric condition (3-D) to the equivalent plane strain (2-D) condition (Hird et al., 1992; Indraratna and Redana, 1997, 2000). Based on the method proposed earlier by Indraratna and Redana (2000), the relationships between axisymmetric and plane strain permeability coefficients and vacuum pressure in this method are given below.

The equivalent permeability under plane strain is given by (Indraratna and Redana, 1997)

$$
\frac{k_{\mathrm{hp}}}{k_{\mathrm{h}}}=\frac{\left[\alpha+\frac{k_{\mathrm{hp}}}{k_{\mathrm{sp}}} \beta+\theta\left(2 l z-z^{2}\right)\right]}{\left[\ln \left(\frac{n}{s}\right)+\frac{k_{\mathrm{h}}}{k_{\mathrm{s}}} \ln (s)-\frac{3}{4}+\pi\left(2 l z-z^{2}\right) \frac{k_{\mathrm{h}}}{q_{\mathrm{w}}}\right]}
$$

where $\alpha$ and $\beta$ have been defined earlier (see Eq. (8)).

Now, by neglecting the smear effect and well resistance for relatively short drains, the equivalent permeability in the undisturbed zone can be derived as

$$
\frac{k_{\mathrm{hp}}}{k_{\mathrm{h}}}=\frac{[\alpha+\beta]}{[\ln (n)-0.75]}=\frac{\left[\frac{2}{3}\left(1-\frac{1}{n}\right)^{2}\right]}{[\ln (n)-0.75]} \approx \frac{0.67}{[\ln (n)-0.75]}
$$

By rearranging Eq. (12), the equivalent permeability within the smear zone can be determined by (Indraratna and Redana, 2000)

$$
\frac{k_{\mathrm{sp}}}{k_{\mathrm{hp}}}=\frac{\beta}{\frac{k_{\mathrm{hp}}}{k_{\mathrm{h}}}\left[\ln \left(\frac{n}{s}\right)+\frac{k_{\mathrm{h}}}{k_{\mathrm{s}}} \ln (s)-\frac{3}{4}\right]-\alpha}
$$

The equivalent vacuum pressure under plane strain is (Indraratna et al., 2005)

$$
p_{0 \mathrm{p}}=p_{0}
$$

\section{SINGLE DRAIN ANALYSIS}

\subsection{Numerical modeling of vertical drain incorporating vacuum preloading}

A finite element program (ABAQUS) was employed to simulate the unit cell of a vertical drain and the results were compared with the analytical model. The ABAQUS (Hibbitt 
et al., 2004) has been designed as a flexible tool for multipurpose finite element analysis, with the feature of the boundary modification for vacuum pressure application. The soft clay and vertical drain properties are shown in Table 1. In the field, zero lateral displacement could be justified at the embankment centreline (i.e. $v=0.0$ ) and the horizontal soil permeability was determined to be appoximately $10^{-10} \mathrm{~m} / \mathrm{s}$. The top, bottom, and outer boundaries were set as impermeable (see Figure 5), and the vertical loading pressure $\left(\sigma_{1}=100 \mathrm{kPa}\right)$ was applied to the top of the cell. The horizontal displacement boundary was fixed, while vertical displacement was permitted and a VPR of unity was also employed (i.e. $p_{0} / u_{0}=1.0$ ). To ensure an equal strain condition, rigid elements were selected at the soil surface and the following two cases were then examined:

Case i: Analysis of short drains. According to the laboratory equipment, the unit cell was $450 \mathrm{~mm}$ diameter (i.e. $d_{\mathrm{e}}$ or $2 B$ ), and $950 \mathrm{~mm}$ high. The equivalent drain diameter $\left(d_{\mathrm{w}}\right)$ or drain width $\left(2 b_{\mathrm{w}}\right)$ was taken to be $50 \mathrm{~mm}$. A total of 160 elements (eight-node bi-quadratic displacement and bilinear pore pressure) were used in the finite element mesh (Figure 5a). The maximum aspect ratio of elements was not more than 3 . To simulate the drain boundary, pore pressure was set to zero for the conventional case (no vacuum pressure), or specified to be maximum (negative) at the top, reducing linearly to $75 \%$ of applied vacuum pressure at the bottom $\left(k_{1}=0.75\right)$. This agreed with the laboratory results shown earlier in Figure 2.

Case ii: Analysis of long drains. The dimensions of the unit cell and vertical drain were the same as Case i. For relatively long vertical drains, the soil height was increased to 10 $\mathrm{m}$, and the vacuum pressure at the bottom of the drain was taken to be zero $\left(k_{1}=0.00\right)$. The pore pressure at the drain boundary was set to maximum $\left(-p_{0}\right)$ at the top, reducing linearly to zero at the bottom (Figure 5b).

\subsection{Comparison between axisymmetric and equivalent plane strain analyses}

For multidrain simulation, plane strain finite element analysis can be readily adapted to most field situations for the reasons explained earlier (Hansbo, 1981, 1997; Indraratna and Redana, 1997, 2000; Indraratna et al., 2004, 2005). For this study, the $c_{\mathrm{h}}=3.15 \mathrm{~m}^{2} / \mathrm{yr}$ and $r_{\mathrm{e}}=225 \mathrm{~mm}$ were used in the analysis. The discrepancy between the axisymmetric and plane strain conditions (before conversion), with and without vacuum preloading, are

Table 1. Soil and vertical drain properties used in the unit cell

\begin{tabular}{lc}
\hline Soil and vertical drain properties & Magnitude \\
\hline$m_{\mathrm{v}}\left(\mathrm{m}^{2} / \mathrm{kN}\right)$ & $1.00 \times 10^{-4}$ \\
Vacuum pressure $(\mathrm{kPa})$ & 100 \\
$k_{\mathrm{h}}(\mathrm{m} / \mathrm{s})$ & $1.00 \times 10^{-10}$ \\
$k_{\mathrm{h}} / k_{\mathrm{s}}$ & 10.0 \\
$d_{\mathrm{w}}(\mathrm{m})$ & 0.05 \\
$d_{\mathrm{s}}(\mathrm{m})$ & 0.17 \\
$d_{\mathrm{e}}(\mathrm{m})$ & 0.45 \\
\hline
\end{tabular}



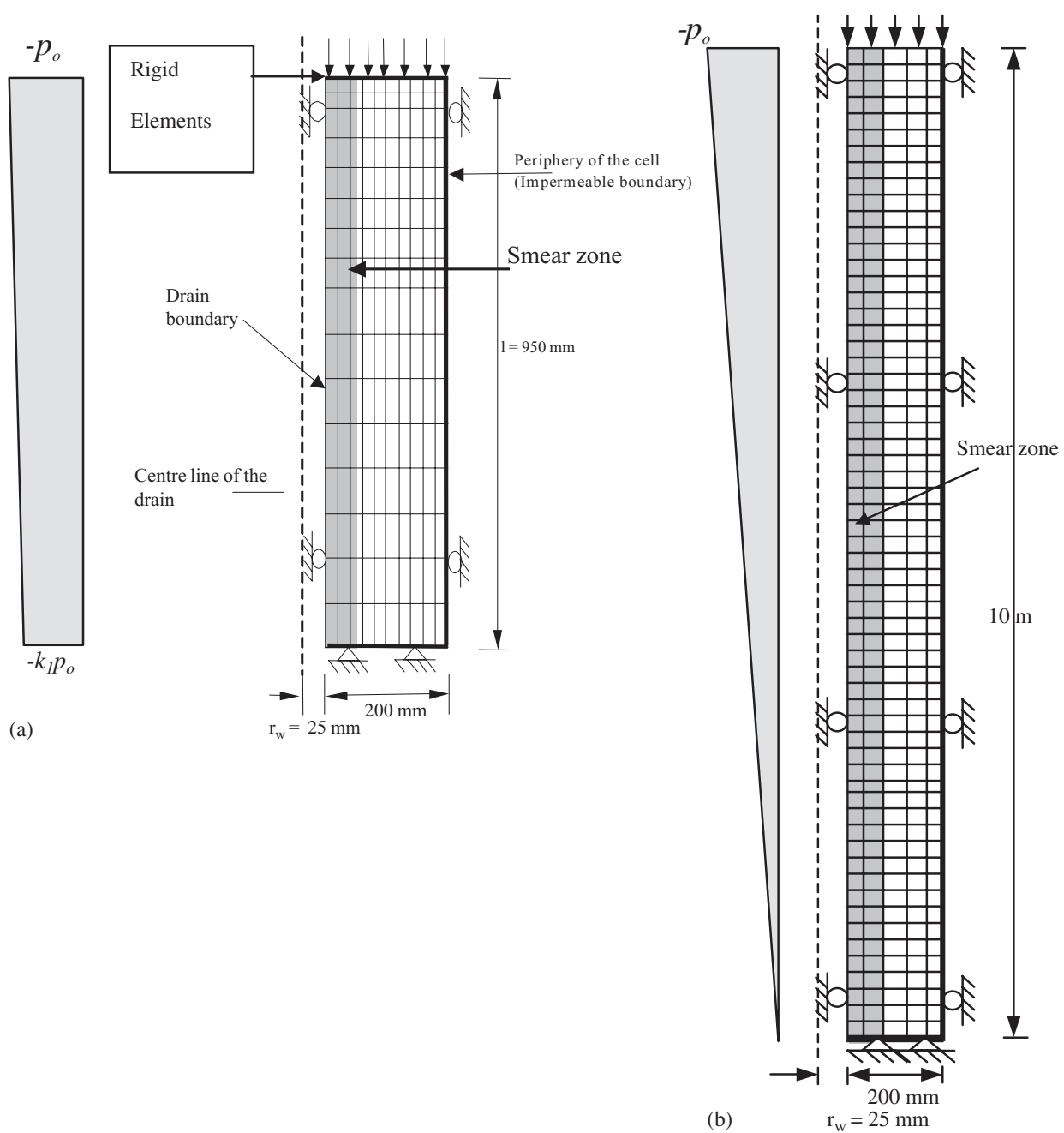

Figure 5. Finite element discretization for axisymmetric and plane strain analyses of soil in unit cell: (a) for short drain analysis (Case i), (b) for long drain analysis (Case ii).

shown in Figure 6. The decrease in average excess pore pressure for the axisymmetric case is slower than the plane strain because in the unit cell, the area of a drain wall is greater than a drain well. Figure 6 also shows that the final average excess pore pressure becomes zero after 250 days $\left(T_{\mathrm{h}} \approx 42.7\right)$ under axisymmetric conditions, whereas the time for zero excess pore water pressure is about 50 days under plane strain condition $\left(T_{\mathrm{h}} \approx 8.53\right)$. As expected, the $25 \%$ vacuum loss along the drain (Case i) shows a greater average excess pore pressure dissipation rate than the $100 \%$ vacuum loss along the drain (Case ii). 


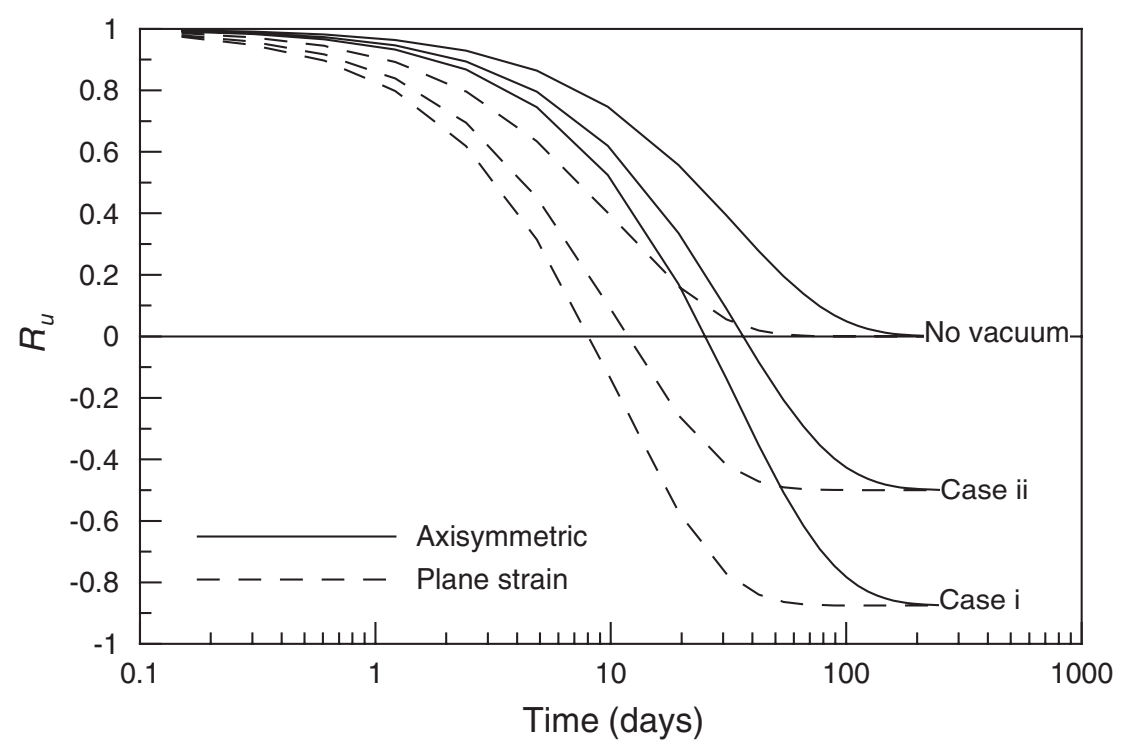

Figure 6. Difference between original axisymmetric and plane strain analyses before establishing the equivalent plane strain conversion $\left(c_{\mathrm{h}}=3.2 \mathrm{~m}^{2} / \mathrm{yr}, r_{\mathrm{e}}=225 \mathrm{~mm}\right)$.

Table 2. Permeability coefficient and vacuum pressure values for axisymmetric and equivalent plane strain conditions

\begin{tabular}{lcc}
\hline Conversion parameters & Axisymmetric & Equivalent plane strain \\
\hline Undisturbed permeability $\left(\times 10^{-10} \mathrm{~m} / \mathrm{s}\right)$ & 1.00 & 0.463 (Eq. (13)) \\
Smear permeability $\left(\times 10^{-10} \mathrm{~m} / \mathrm{s}\right)$ & 0.10 & 0.032 (Eq. (14)) \\
Vacuum pressure $(\times 100 \mathrm{kPa})$ & 0.50 & 0.50 (Eq. (15)) \\
\hline
\end{tabular}

Figure 6 demonstrates that the axisymmetric and plane strain solutions cannot provide the same consolidation response. Therefore, it is imperative to employ an appropriate conversion procedure to obtain an equivalent plane strain solution that offers a very good match to the axisymmetric consolidation curve. To examine the validity of the proposed conversion procedure, the analytical and numerical models were employed to compare deviations between the axisymmetric and equivalent plane strain conditions. Based on Eqs. (12)-(15), the parameters used in the axisymmetric and equivalent plane strain conditions for both short and long drain analyses (i.e. Cases i and ii) are shown in Table 2.

After conversion of the original axisymmetric condition into the equivalent plane strain, the results are identical as shown in Figure 7. A comparison of Figures 7(a) and (b) verifies that the finite element and analytical model results coincide; hence, for the purpose of 


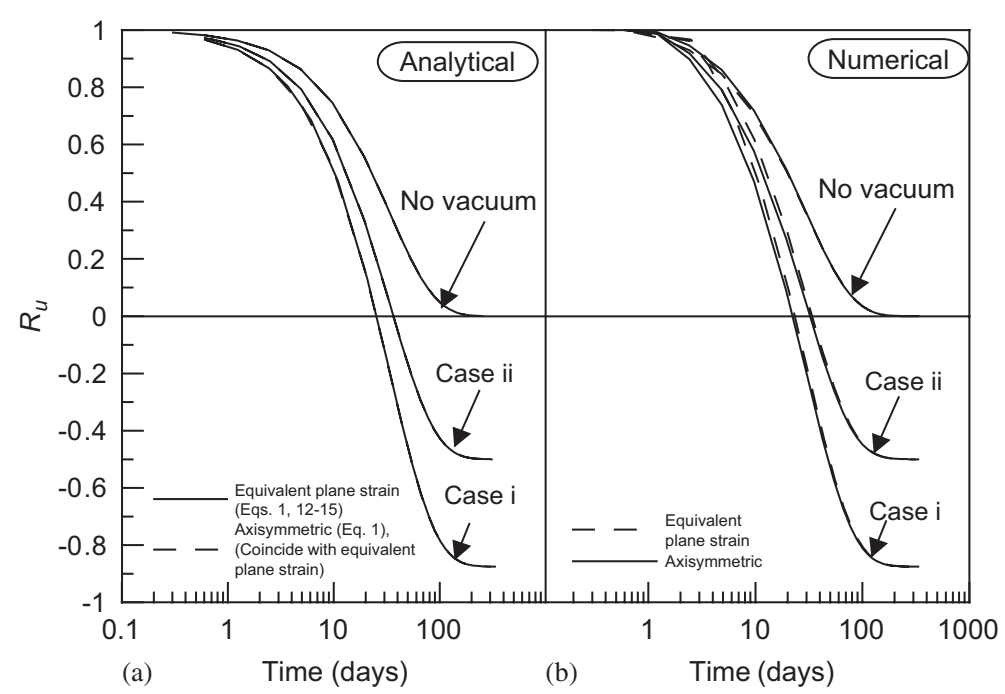

Figure 7. Comparison of axisymmetric model with the equivalent plane strain model:(a) analytical method, (b) finite element method.

clarity, the analytical and finite element data are plotted separately. This conversion procedure establishes the reliability of the equivalent plane strain model for Cases i and ii.

\subsection{Influence of magnitude and distribution of vacuum pressure}

The effect of the value of vacuum pressure and distribution of vacuum pressure along the vertical drain is discussed in this section. The comparison of settlement with different VPR for Cases i and ii, as well as conventional cases, are shown in Figures 8(a) and (b), respectively. As expected, the rate of settlement with applied vacuum pressure was faster than the conventional loading (surcharge only) without any vacuum pressure. Figure 8 also shows that, at the higher VPR, the settlement rate and ultimate settlement are increased. It is also verified that the application of vacuum pressure increases the lateral pore pressure gradient, promoting radial flow. This accelerated consolidation and increases the rate of settlement and final settlement. This is similar to increasing the applied surcharge load but without increasing the generated excess pore water pressure. This consideration of varying vacuum pressure along the length of drain is more realistic because the effect of vacuum pressure diminishes with depth (Indraratna et al., 2004). For long vertical drains, it is most probable that the applied vacuum pressure at the drain top may not propagate toward the bottom of the drain. The data plotted in Figure 8 show that the rate of consolidation associated with $25 \%$ vacuum loss (Case i) is greater than Case ii. It is clear that the greater the value of vacuum pressure ratio, the higher the rate of consolidation. In the field, unless the 

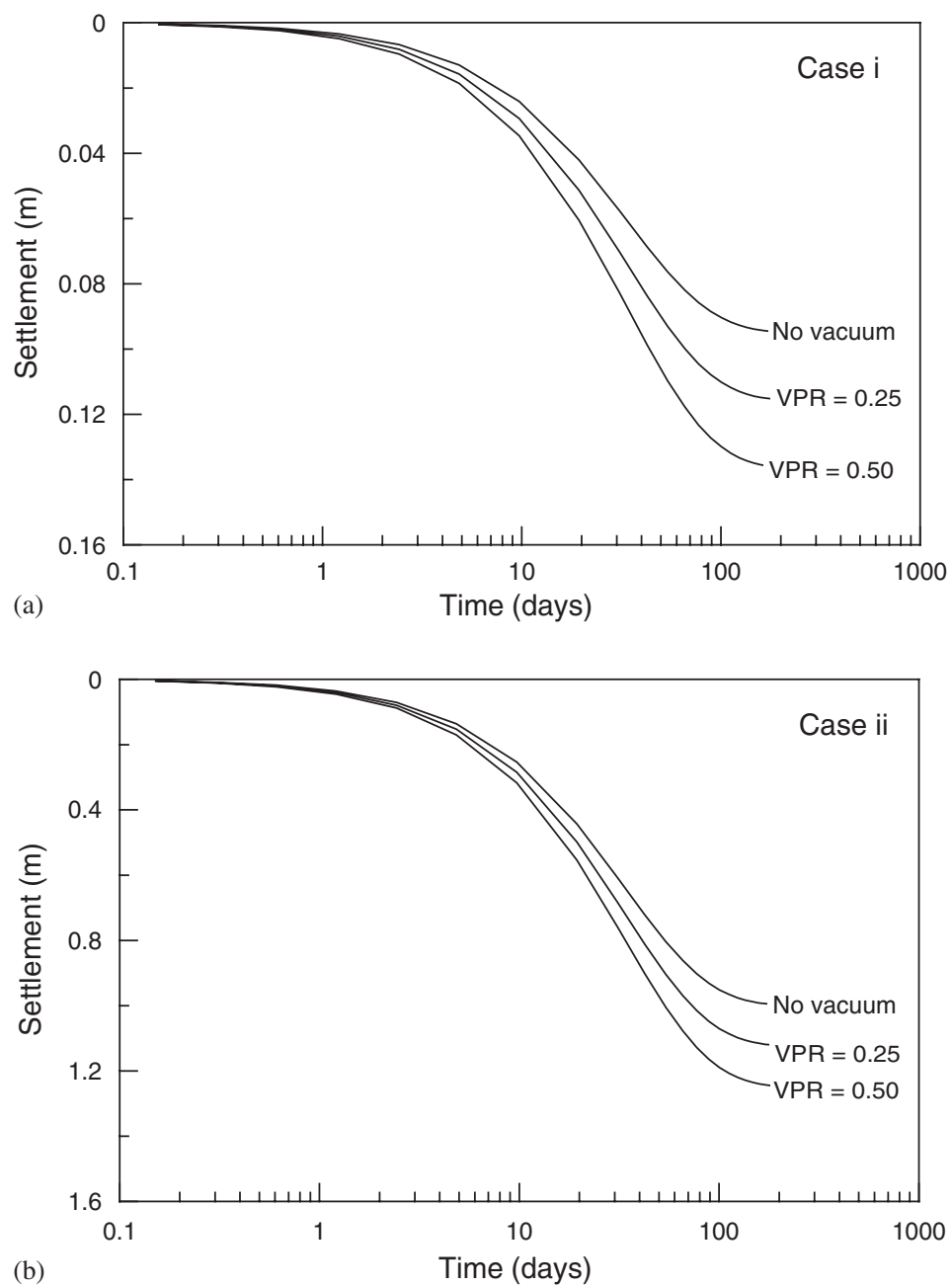

Figure 8. Settlement results from analytical solution:(a) Case i, short drain, (b) Case ii, long drain.

magnitude of suction head is large enough (e.g. VPR $>0.25$ ), the influence on excess pore pressure dissipation may be insignificant.

\section{APPLICATION OF MODEL TO CASE HISTORIES}

\subsection{Site characteristics and embankment details}

The Second Bangkok International Airport or Suvarnabhumi Airport is located about 30 $\mathrm{km}$ from the city of Bangkok. The exact location of this site in the Samut Prakan province 
is shown in Figure 9. In this area, soft clays, mainly of marine or deltaic origin, often present considerable construction problems, which requires ground improvement techniques to prevent excessive settlement and lateral movement.

The subsoil profile at the site consists of the $2.0 \mathrm{~m}$ upper thick weathered crust (highly overconsolidated clay) overlying a very soft to medium clay, which extends about $10 \mathrm{~m}$ below the ground surface. Underneath the medium clay layer, a light-brown stiff clay layer is found at a depth of $10-21 \mathrm{~m}$. The ground-water level fluctuates between 0.5 and $1.5 \mathrm{~m}$ below the surface. The soil profile with the strata properties is illustrated in Figure 10. The water content of the very soft clay layer varies from 80 to $100 \%$, whereas in the lower parts of the stratification (10-14 m) it changes from 50 to $80 \%$. The plastic and liquid limits of the soil in each layer are similar and found to be in the range of $80-100 \%$ and $20-40 \%$, respectively (Figure 10).

The shear strength and compressibility indices of subsoil layers including the compressibility index and over-consolidation ratio (OCR) are given in Figure 11 (Sangmala, 1997). The minimum undrained shear strength $\left(C_{\mathrm{u}}\right)$ of topmost weathered clay is about 18 $\mathrm{kPa}$ at a depth of $1 \mathrm{~m}$. This value decreases to $8-15 \mathrm{kPa}$ in the very soft underlying clay layer, which is highly compressible. The weathered crust is much less compressible due to its desiccation and compaction. The compression index of the soft clay layer varies from 0.3 to 0.5 , whereas the weathered crust has a compressibility index of about 0.2 . The soil layers below the upper crust are lightly over-consolidated (OCR 1.0-1.8).

At this airport site, several trial embankments were constructed, two of which, TV1 and TV2, were built with PVDs and vacuum application (Figure 12). Total base area of each embankment was $40 \times 40 \mathrm{~m}^{2}$ (Asian Institute of Technology, 1995). Figures 13 and 14 present the cross-sections and positions of the field instruments for embankments TV1 and TV2, respectively. For TV1 (Figure 13), 15 m-long PVDs with a hypernet drainage system were installed, and for TV2 (Figure 14), 12 m-long PVDs with perforated and corrugated pipes wrapped together in non-woven geotextile were used. The drainage blanket (working platform) was constructed with sand 0.3 and $0.8 \mathrm{~m}$ for embankments TV1 and TV2, respectively with an air and watertight linear low density polyethylene (LLDPE) geomembrane liner placed on top of the drainage system. This liner was sealed by placing its edges at the bottom of the perimeter trench and covered with a $300 \mathrm{~mm}$ layer of bentonite and then submerged with water. The PVDs were installed in a triangular pattern at a spacing of $1 \mathrm{~m}$ (Table 3).

In each embankment, a vacuum pressure up to $525 \mathrm{mmHg}(70 \mathrm{kPa}$ ) could be achieved using the available vacuum equipment. This pressure is equivalent to a fill height of $4 \mathrm{~m}$. After 45 days of vacuum application, the surcharge load was applied in four distinct stages upto $2.5 \mathrm{~m}$ high (the unit weight of surcharge fill equals to $18 \mathrm{kN} / \mathrm{m}^{3}$ as illustrated in Figure 15. Field instrumentations including surface settlement plates, subsurface multipoint extensometers, vibrating wire electrical piezometers and inclinometers were installed. In addition, around the dummy area, observation wells and stand-pipe piezometers were installed. The settlement, excess pore water pressure, and lateral movement, were observed for 5 months. 


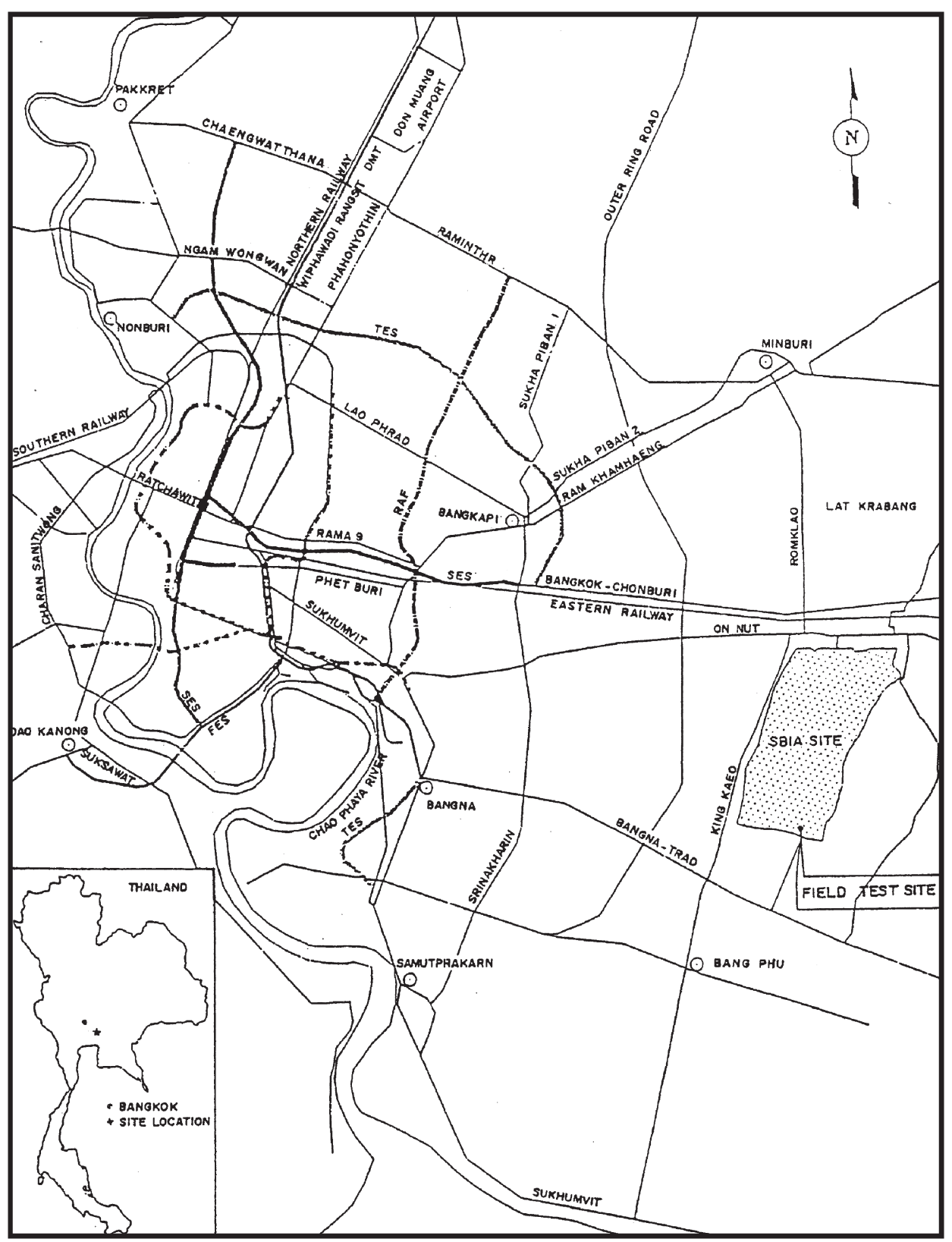

Figure 9. Location of the Second Bangkok International Airport (after Suvarnabhumi Airport, 2004). 


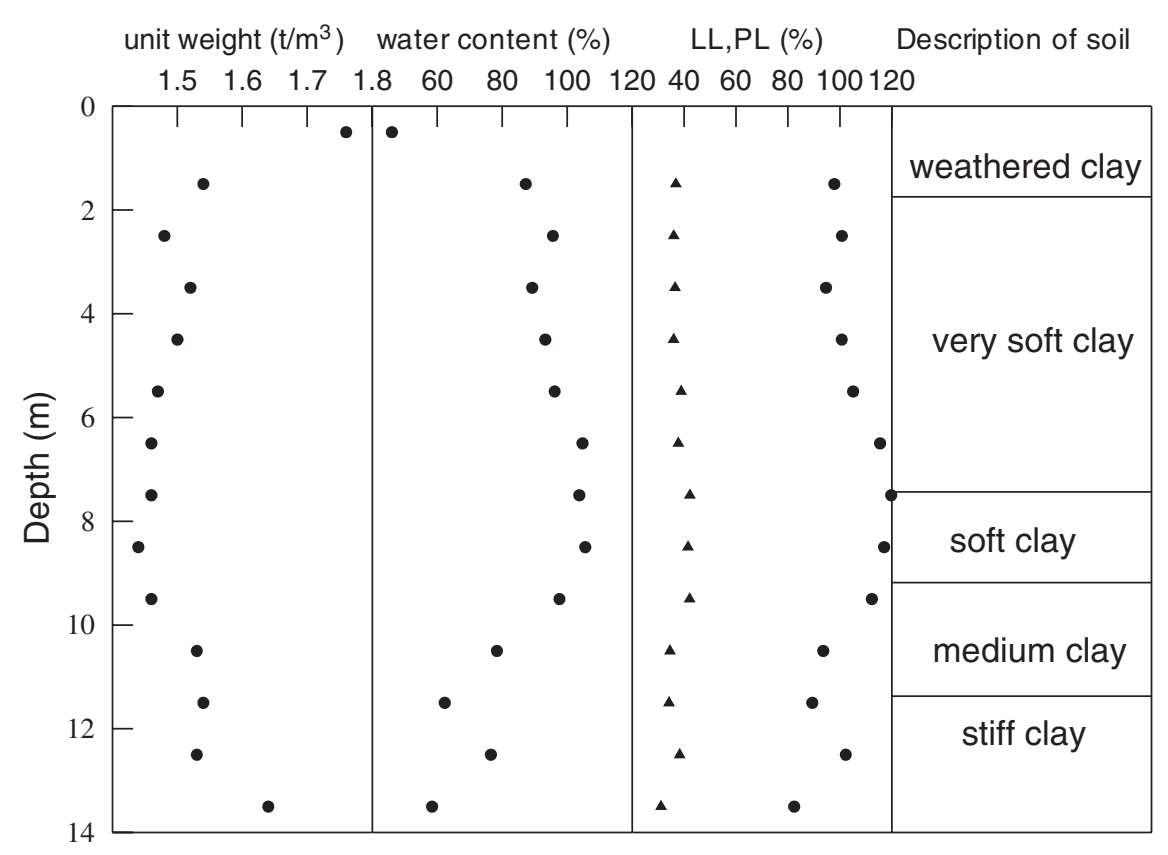

Figure 10. General soil profile and properties at Second Bangkok International Airport (after Sangmala, 1997).

\subsection{Numerical analysis incorporating vacuum pressure}

Indraratna and Rujikiatkamjorn (2004) and Indraratna et al. (2004, 2005) investigated the performance of ground improvement by PVDs with vacuum application on this soft Bangkok clay. The consolidation behavior of soft clay beneath the embankments combined with vacuum and surcharge preloading was analysed using the finite element software ABAQUS. The equivalent plane strain, Eqs. (12)-(15), as well as the modified Cam-clay theory (Roscoe and Burland, 1968) were incorporated in the analysis. The parameters of subsoil layers based on laboratory testing are given in Table 4. According to Indraratna and Redana (1997), the ratio of $k_{\mathrm{h}} / k_{\mathrm{s}}$ and $d_{\mathrm{s}} / d_{\mathrm{w}}$ determined in the laboratory is approximately $1.5-2.0$ and 3-4, respectively, but in practice these ratios can vary from 1.5 to 10 depending on the type of drain and installation procedures used (Indraratna and Redana, 2000; Saye, 2003). The values of $k_{\mathrm{h}} / k_{\mathrm{s}}$ and $d_{\mathrm{s}} / d_{\mathrm{w}}$ for this case study were assumed to be 10 and 6, respectively (Table 4) (Indraratna et al., 2005). For the plane strain finite element method (FEM) simulation, the equivalent permeability inside and outside the smear zone was determined using Eqs. (12) and (14). The discharge capacity $\left(q_{\mathrm{w}}\right)$ of 50 $\mathrm{m}^{3} / \mathrm{yr}$ was derived using Eq. (16); hence as proposed by Hird et al. (1992),

$$
k_{\mathrm{wp}}=q_{\mathrm{w}} / 2 b_{\mathrm{w}}
$$




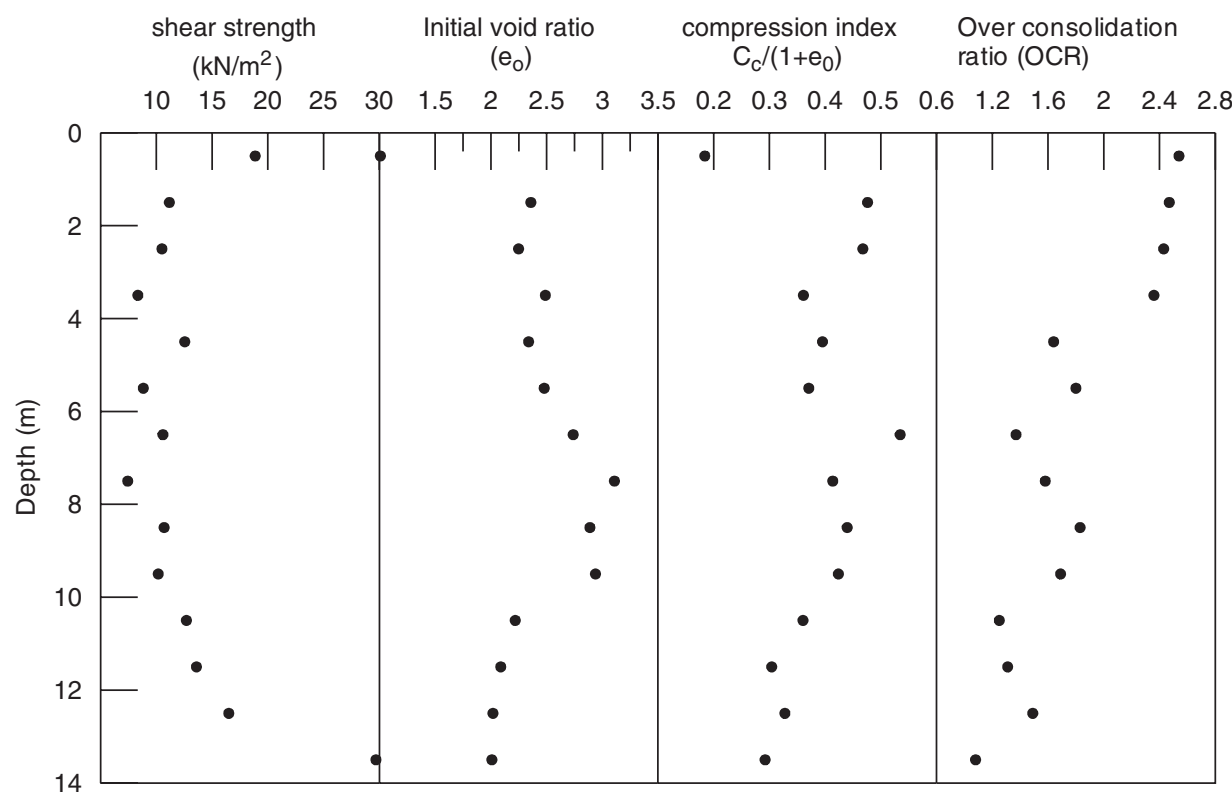

Figure 11. Average strength and compressibility parameters at Second Bangkok International Airport (after Sangmala, 1997).

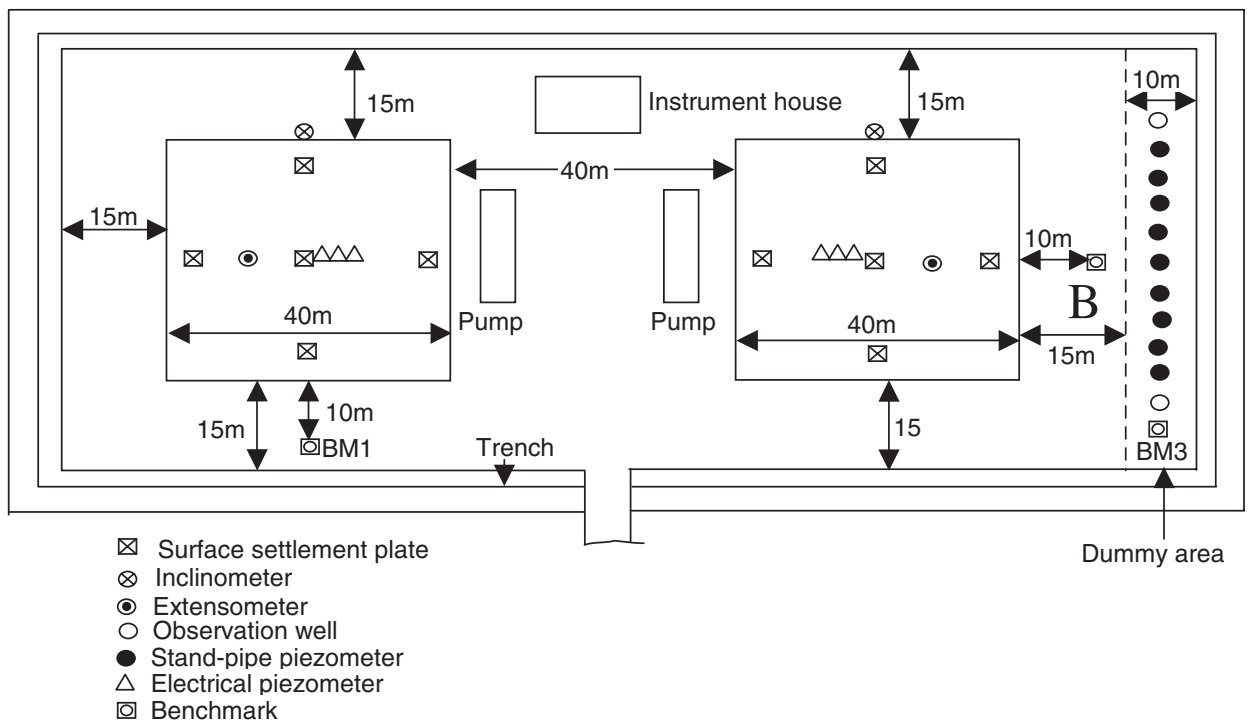

Figure 12. Site plan for the test embankments at Second Bangkok International Airport (after Sangmala, 1997). 


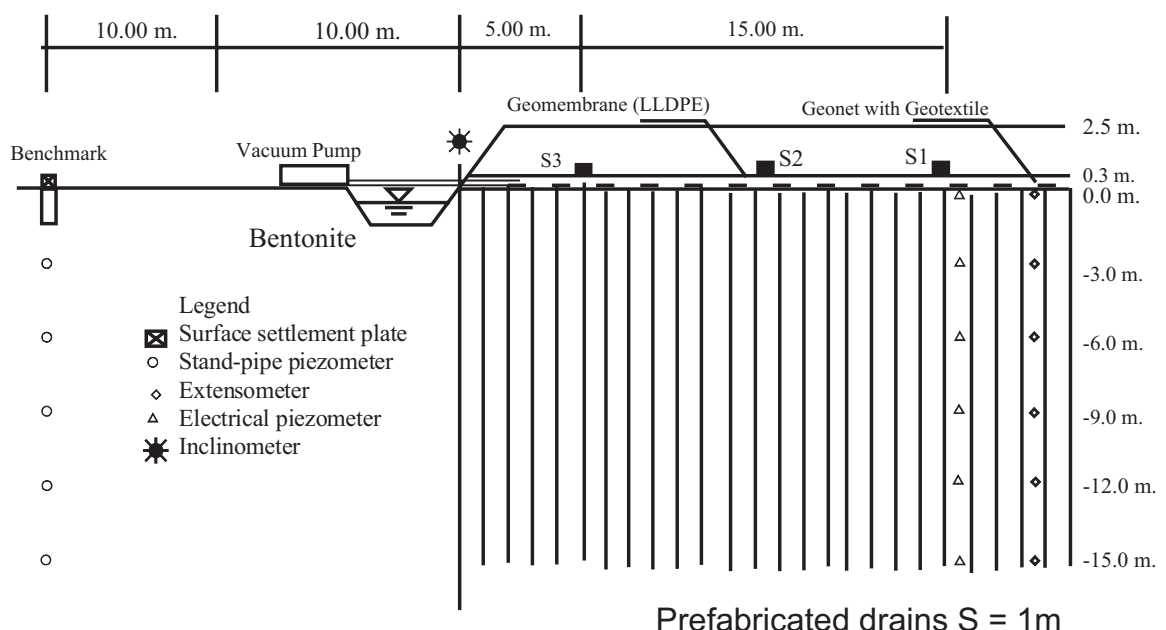

Figure 13. Vertical cross-section at embankment TV1 with instrumentation locations (adapted from AIT, 1995).

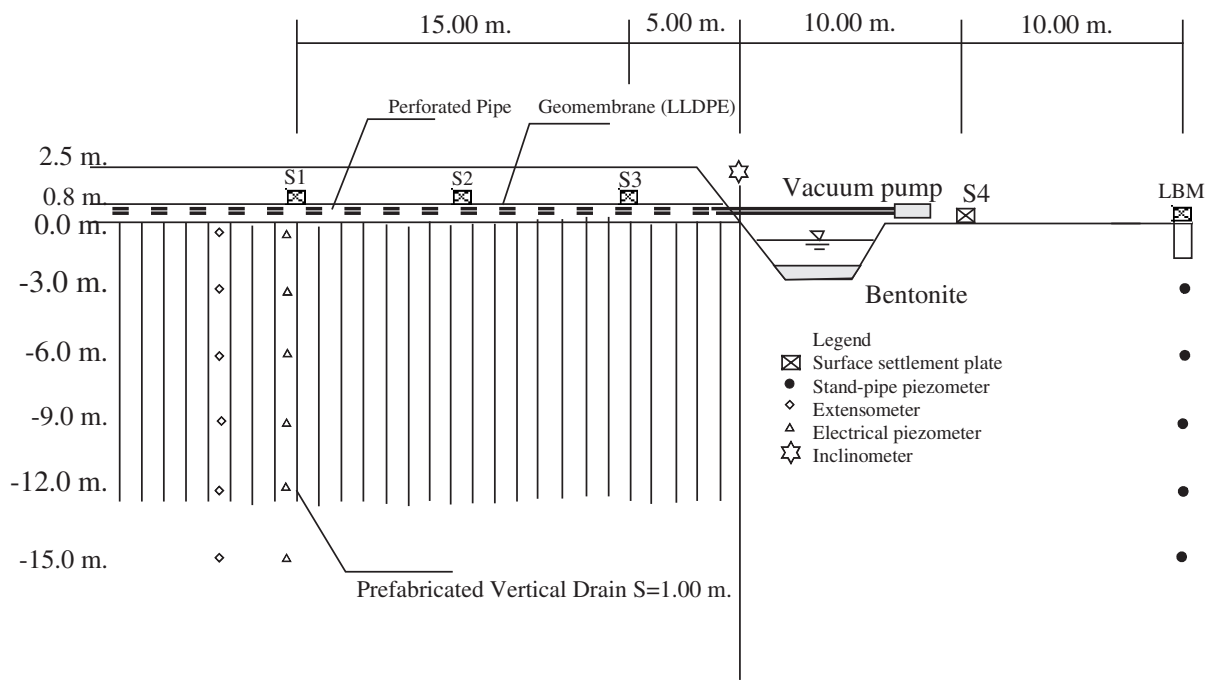

Figure 14. Vertical cross section at embankment TV2 with instrumentation locations (adapted from AIT, 1995).

The finite element mesh contained eight-node bi-quadratic displacement and bilinear pore pressure elements (Figure 16). Only the right-hand side of the embankment was modelled the finite element analysis by symmetry, as shown in Figure 16. For the PVD zone and smear zone, a finer mesh was implemented so that each unit cell represented a single drain 
Table 3. Vertical drain parameters

\begin{tabular}{ll}
\hline Spacing, $S$ & $1.0 \mathrm{~m}$ (triangular) \\
\hline Diameter of drain, $d_{\mathrm{w}}$ & $50 \mathrm{~mm}$ \\
Discharge capacity, $q_{\mathrm{w}}$ & $50 \mathrm{~m}^{3} / \mathrm{yr}$ (per drain) \\
Length of vertical drain & $15 \mathrm{~m} \mathrm{for} \mathrm{TV1} \mathrm{and} 12$ \\
& $\mathrm{~m}$ for TV2 \\
\hline
\end{tabular}

Source: Indraratna et al., (2005).

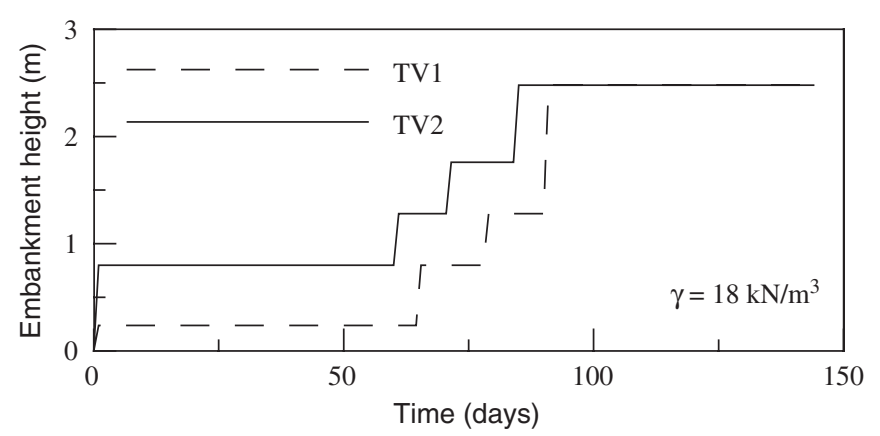

Figure 15. Multistage loading for embankments TV1 and TV2 (after Indraratna and Rujikiatkamjorn, 2004).

Table 4. Selected soil parameters in FEM analysis

\begin{tabular}{lcccccccccc}
\hline Depth (m) & $\lambda$ & $\kappa$ & $v$ & $e_{0}$ & $\begin{array}{c}\gamma \\
\left(\mathrm{kN} / \mathrm{m}^{3}\right)\end{array}$ & $\begin{array}{c}k_{\mathrm{v}} \\
\left(10^{-9} \mathrm{~m} / \mathrm{s}\right)\end{array}$ & $\begin{array}{c}k_{\mathrm{h}} \\
\left(10^{-9} \mathrm{~m} / \mathrm{s}\right)\end{array}$ & $\begin{array}{c}k_{\mathrm{s}} \\
\left(10^{-9} \mathrm{~m} / \mathrm{s}\right)\end{array}$ & $\begin{array}{c}k_{\mathrm{hp}} \\
\left(10^{-9} \mathrm{~m} / \mathrm{s}\right)\end{array}$ & $\begin{array}{c}k_{\mathrm{sp}} \\
\left(10^{-9} \mathrm{~m} / \mathrm{s}\right)\end{array}$ \\
\hline $0.0-2.0$ & 0.3 & 0.03 & 0.30 & 1.8 & 16 & 15.1 & 30.1 & 89.8 & 6.8 & 3.45 \\
$2.0-8.5$ & 0.7 & 0.08 & 0.30 & 2.8 & 15 & 6.4 & 12.7 & 38.0 & 2.9 & 1.46 \\
$8.5-10.5$ & 0.5 & 0.05 & 0.25 & 2.4 & 15 & 3.0 & 6.0 & 18.0 & 1.4 & 0.69 \\
$10.5-13.0$ & 0.3 & 0.03 & 0.25 & 1.8 & 16 & 1.3 & 2.6 & 7.6 & 0.6 & 0.30 \\
$13.0-15.0$ & 1.2 & 0.10 & 0.25 & 1.2 & 18 & 0.3 & 0.6 & 1.8 & 0.1 & 0.07 \\
\hline
\end{tabular}

Source: Indraratna et al., (2005).

with the smear zone established on either side. The finer mesh was imperative to prevent an unfavourable aspect ratio of the elements (Indraratna and Redana, 2000). The incremental surcharge loading was simulated at the upper boundary.

\subsection{Simulation of vacuum consolidation}

Figure 17 illustrates pore water pressure measured every $3 \mathrm{~m}$ deep by the electrical piezometers installed $0.5 \mathrm{~m}$ away from the centerline (AIT, 1995). After 40 days, a discrepancy between the measured and applied vacuum pressure was noted and attributed to the loss of 


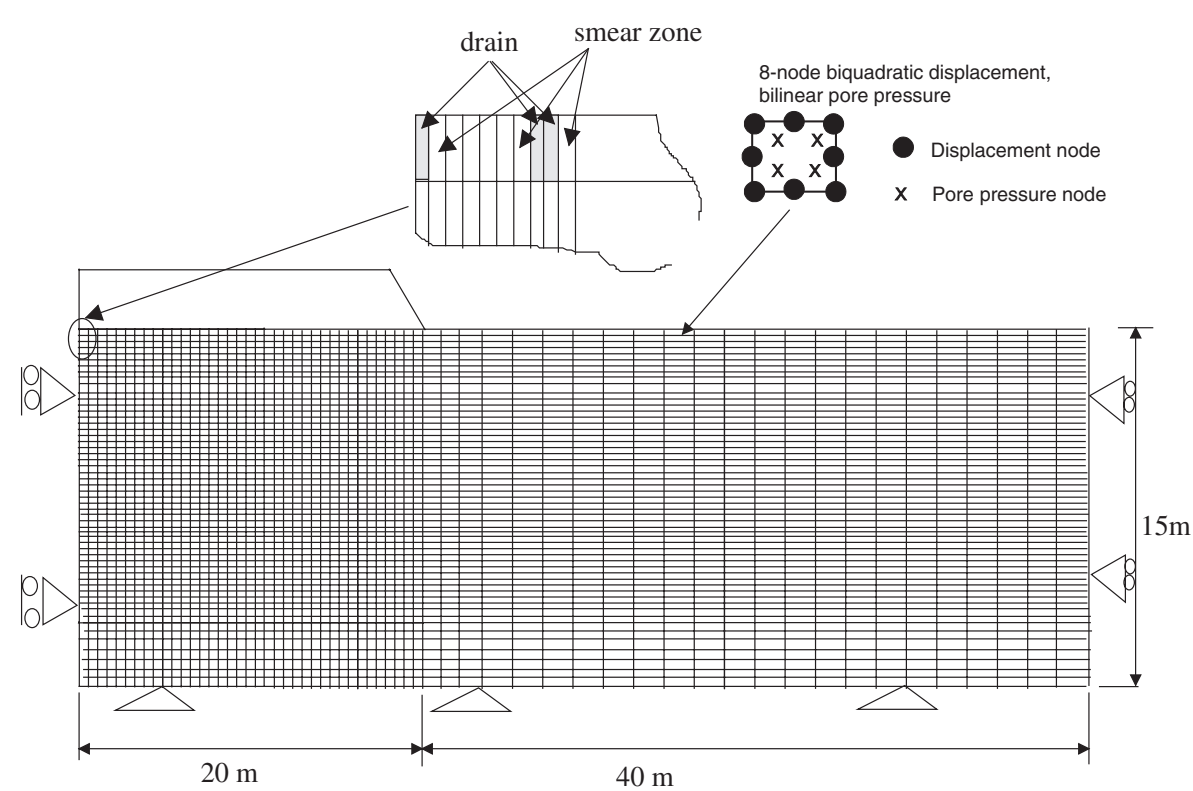

Figure 16. Finite element mesh for plane strain analysis (Indraratna et al., 2005).

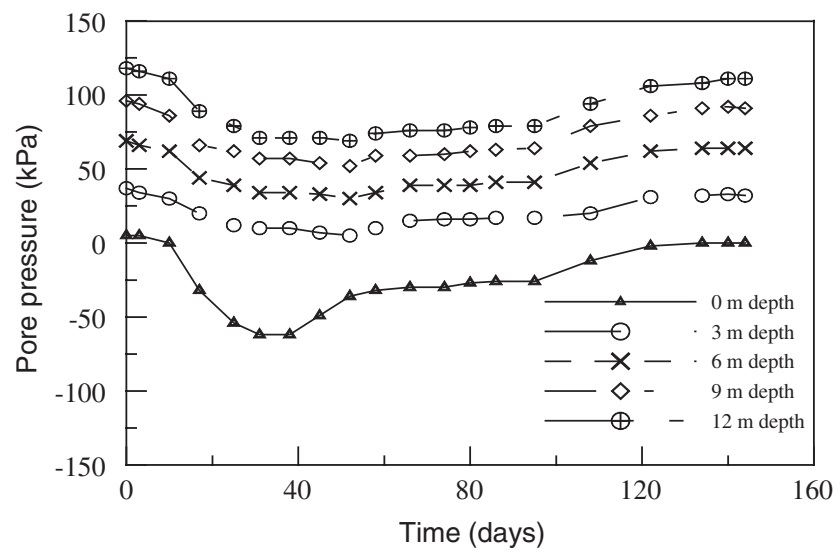

Figure 17. Pore pressure of embankment TV2 at various depths (modified after Indraratna and Rujikiatkamjorn, 2004).

suction head in the field due to an airleak from the membrane (Indraratna et al., 2004). Therefore, in the numerical analysis, the magnitude of applied vacuum pressure at the surface and the top of the drains needed to be adjusted, based on the field observations (Indraratna et al., 2005). Figure 18 illustrates the assumed time-dependent vacuum pressure 


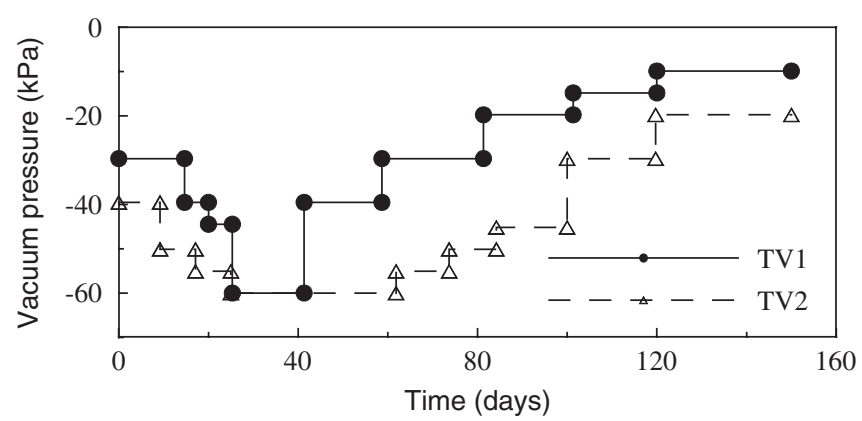

Figure 18. Vacuum pressure values applied in the analysis for Model B (adapted from Indraratna and Rujikiatkamjorn, 2004).

variation applied at the surface taking the airleak into account. The following four models were numerically examined under the plane strain multidrain analysis:

1. Model A: Conventional analysis (i.e. no vacuum application).

2. Model B: Vacuum pressure is adjusted according to field measurement and reduces linearly to zero at the bottom of the drain $\left(k_{1}=0\right)$.

3. Model C: No vacuum loss (i.e. vacuum pressure was kept constant at $-60 \mathrm{kPa}$ after 40 days); vacuum pressure varies linearly to zero along the drain length $\left(k_{1}=0\right)$.

4. Model D: Constant time-dependent vacuum pressure throughout the layer $\left(k_{1}=1\right)$.

Figure 19 compares surface settlement between prediction and measurement (centreline) for embankment TV1. Model B predictions agree with the field data. Figure 20 illustrates the comparison of subsurface settlement between Model B predictions and the field measurements. For the embankment TV2, the predicted and measured surface settlement and the subsurface settlement at the centreline of the embankment are shown in Figures 21 and 22, respectively. Clearly, Model B predicts the settlement of this embankment very well (Figure 22). Comparing all the different vacuum pressure conditions, Models A and $\mathrm{D}$ give the lowest and highest settlement, respectively. A vacuum application combined with a PVD system can accelerate the consolidation process significantly. With vacuum application most of primary consolidation is achieved around 120 days, whereas conventional surchage (same equivaent pressure) requires more time to reach primary consolidation (after 150 days). It is also apparent that greater settlement can be attained, if any loss of vacuum pressure can be maintained (Model C).

Based on laboratory observations (Indraratna et al., 2004), the effect of vacuum pressure may diminish along the length of the drain for relatively long PVDs. Field measurements indicate that the pattern of vacuum distribution and the extent of vacuum loss directly influences soil consolidation behaviour. The accuracy of the numerical predictions 


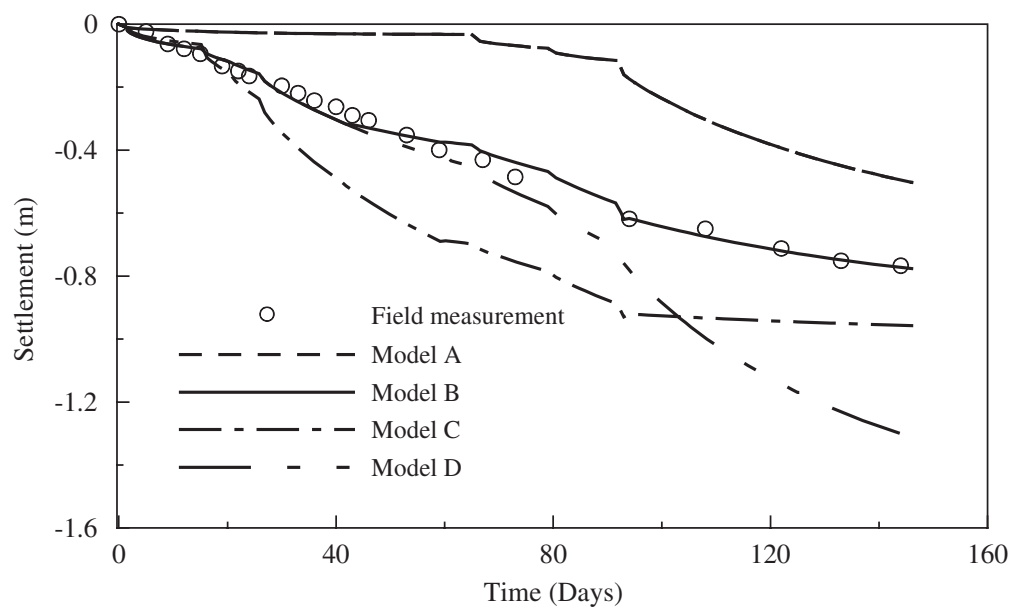

Figure 19. Surface settlement of embankment TV1 (modified after Indraratna and Rujikiatkamjorn, 2004).

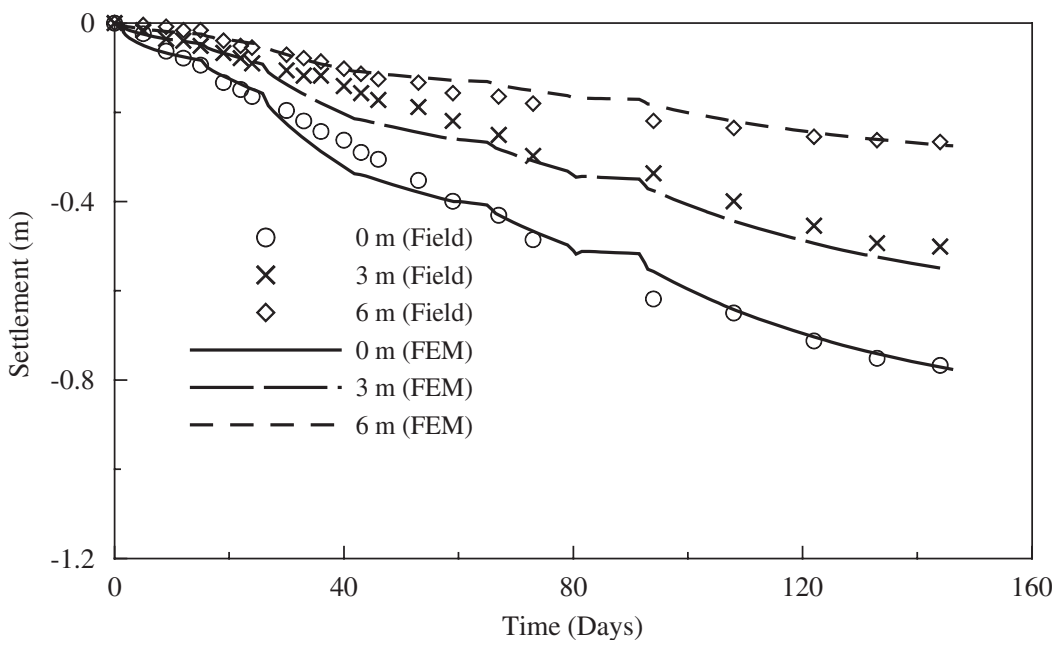

Figure 20. Consolidation settlement of embankment TV1 (Model B) (inspired by Indraratna and Rujikiatkamjorn, 2004).

is governed by correct assumptions of the time-dependent vacuum pressure distribution with soil depth (Indraratna et al., 2005).

The predicted and measured excess pore pressures for embankments TV1 and TV2 are shown in Figures 23 and 24, respectively. According to this analysis, the field data plot is closest to Model B, suggesting that the writers' assumption of linearly decreasing vacuum 


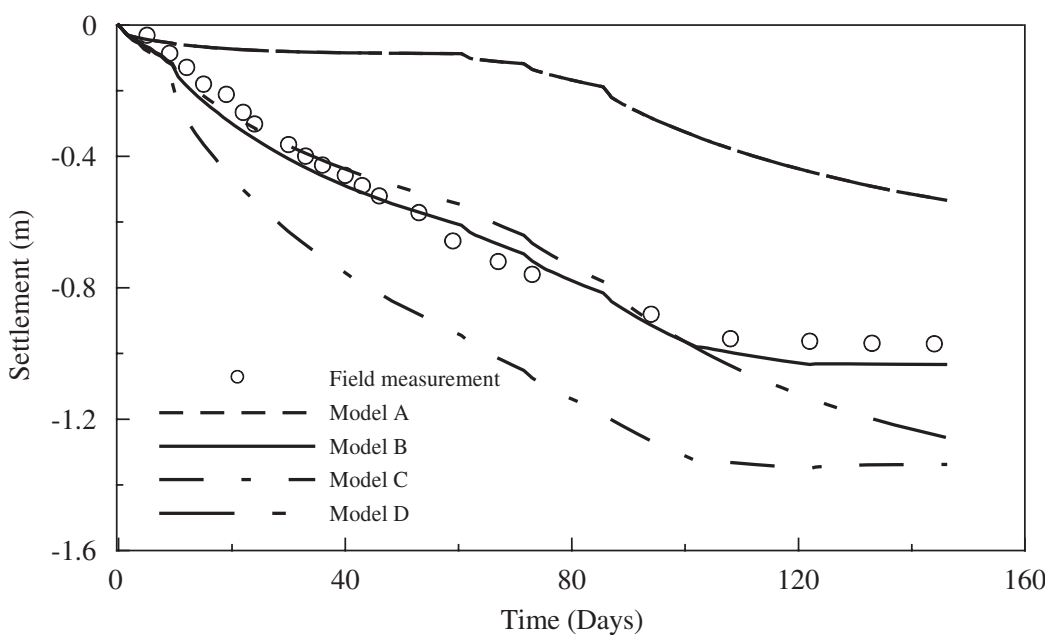

Figure 21. Surface settlement of embankment TV2 (modified after Indraratna et al., 2005).

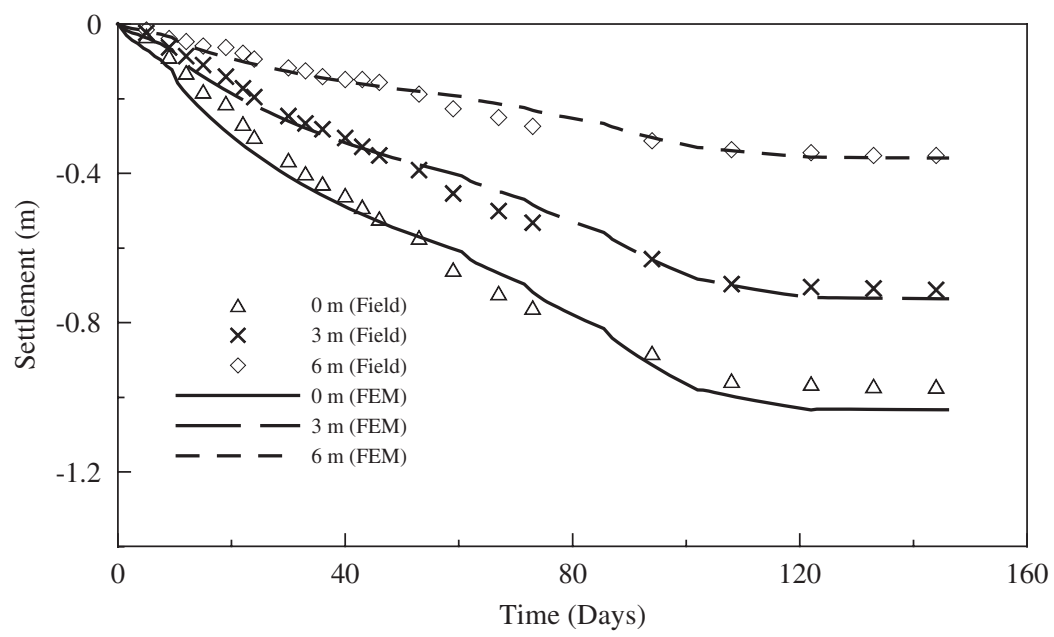

Figure 22. Consolidation settlement of embankment TV2 (Model B) (adapted from Indraratna et al., 2005).

pressure along the drain length is justified. Excess pore pressure generated from the vacuum application is significantly less than from the conventional case, which enables the rate of construction of a vacuum-assisted embankment to be higher than conventional construction.

The predicted and measured lateral displacements (at the end of surcharge construction) are shown in Figure 25. The observed lateral displacements do not seem to agree with 


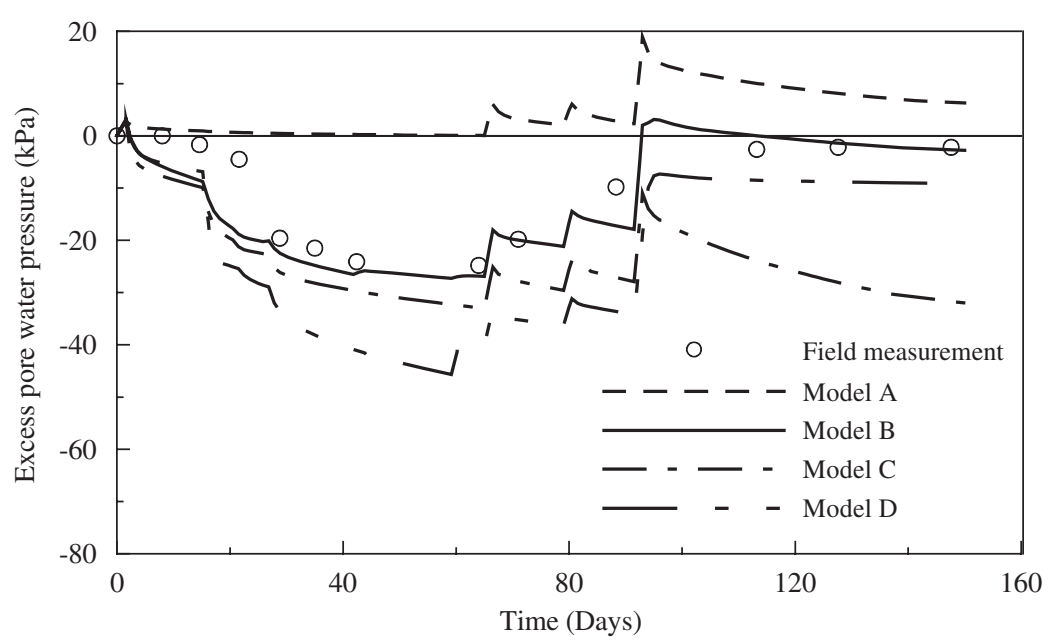

Figure 23. Variation of excess pore water pressure $3 \mathrm{~m}$ deep below the surface and $0.5 \mathrm{~m}$ away from centreline for Embankment TV1.

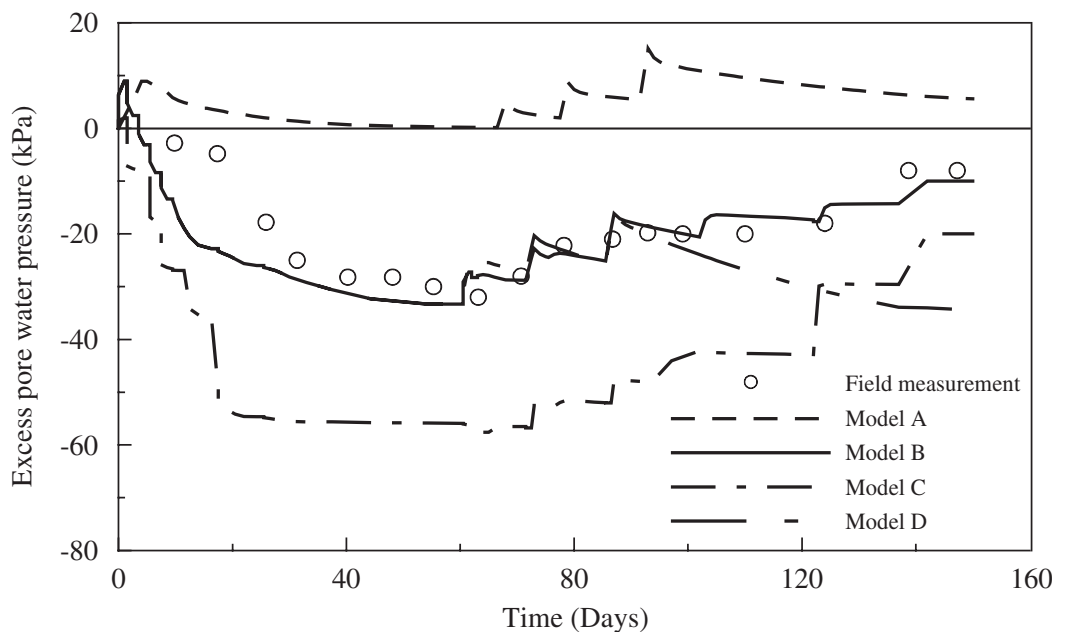

Figure 24. Variation of excess pore water pressure at $3 \mathrm{~m}$ below the surface and $0.5 \mathrm{~m}$ away from centreline for Embankment TV2.

the vacuum pressure models. In the middle of the very soft clay layer (4-5 m deep), the predictions from Models B and C are closest to the field measurements. Nearer to the surface, the field observations do not agree with the 'inward' lateral movements predicted by Models B and C (Indraratna and Rujikiatkamjorn, 2004). The discrepancy between the 


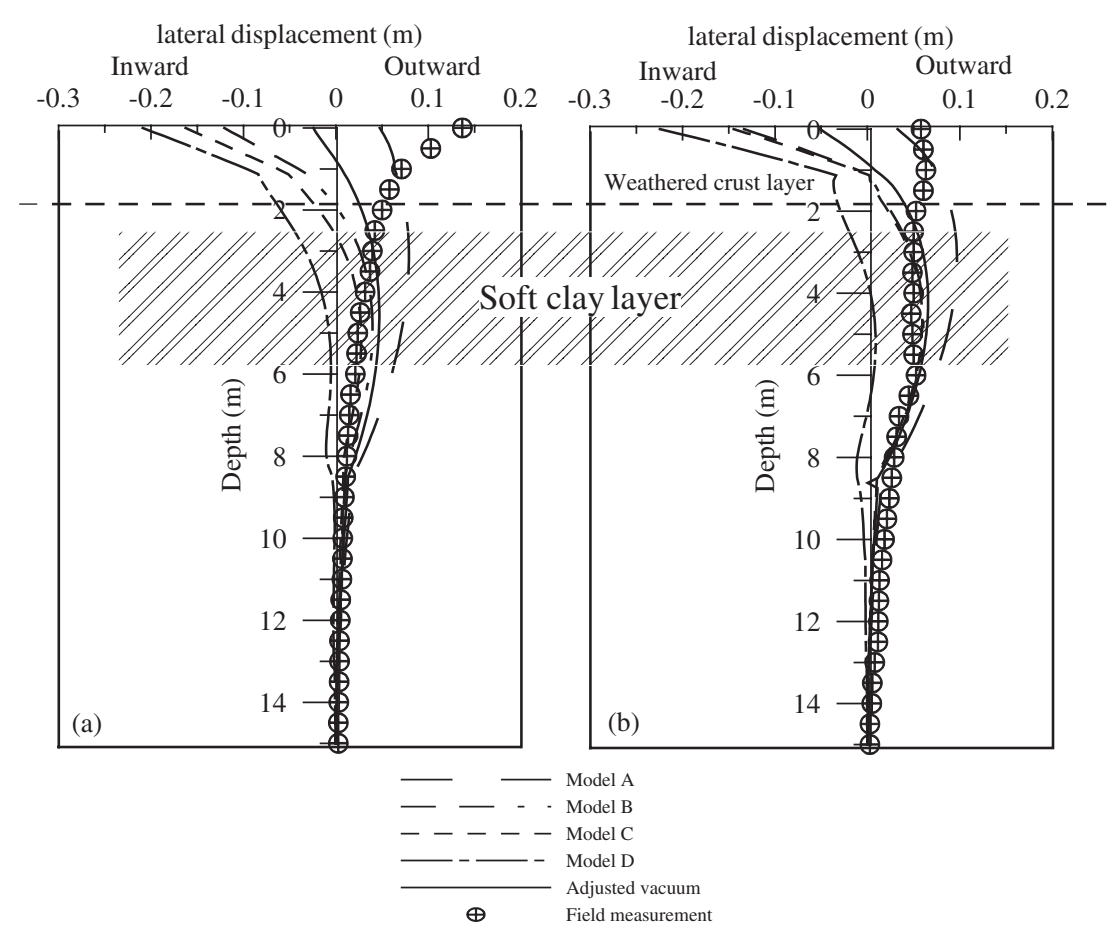

Figure 25. Calculated and measured lateral displacements distribution with depth:(a) embankment TV1 (b) embankment TV2 (after Indraratna and Rujikiatkamjorn, 2004).

finite element models and the measured results is more evident in the topmost weathered crust $(0-2 \mathrm{~m})$. This suggested that the calibration of Model B has a laterally varying vacuum pressure distribution from the centre of the embankment that decreases towards the toe.

Previous studies confirmed that an accurate prediction of lateral movement is a difficult task compared with settlement (Tavenas et al., 1979; Indraratna et al., 1992, 1994). The errors in the lateral displacement predictions can be numerous, mainly attributed to soil anisotropy, the assumption of 2-D plane strain, and corner effects (Indraratna et al., 2005). Moreover, the stiff behaviour of the crust cannot be modelled using conventional CamClay properties, it needs to be modelled as a highly over-consolidated (compacted) layer as discussed in the past by Indraratna et al. (1994).

Vacuum preloading generates an inward lateral movement of soft soil towards the embankment centreline (i.e. negative displacement in Figure 25) and minimized the risk of bearing capacity failure due to rapid embankment. However, this inward movement may cause tension cracks in adjacent areas; hence, lateral movement at the borders of the embankment and its effects on adjacent structures should be carefully monitored (Shang et al., 1998). 


\section{FINAL COMMENTS}

A system of PVDs combined with vacuum preloading is an effective method for accelerating soil consolidation. In this chapter, an analytical model incorporating vacuum preloading has been described for both axisymmetric and equivalent plane strain conditions. A finite element code (ABAQUS) was employed to analyse the unit cell and compare the numerical results with the writers' analytical approach. A conversion procedure based on the transformation of permeability and vacuum pressure was introduced to establish the relationship between the axisymmetric (3-D) and equivalent plane strain (2-D) conditions. The plane strain solution was applied for case history analysis, proving its validity to predict real behaviour. Field behaviour as well as model predictions indicate that the efficiency of vertical drains depends on the magnitude and distribution of vacuum pressure.

A finite element (multi-drain) analysis (ABAQUS) using the authors' equivalent plane strain theory was carried out to evaluate the performance of selected full-scale embankments on soft Bangkok clay. The effects of smear and well resistance associated with PVDs were introduced, together with the applied surcharge load and vacuum pressure. The settlements with depth, excess pore water pressures and lateral movements of the soft clay foundation were analysed and compared with field observations. It was shown that the assumption of vacuum pressure distribution along the drain length is realistic if the spacing is relatively close (i.e. at $1.0 \mathrm{~m}$ ) (Indraratna et al., 2005).

An accurate prediction of lateral displacement depends on the careful assessment of soil properties including the over-consolidated surface crust. This compacted layer is relatively stiff, and therefore it resists 'inward' movement of the soil after vacuum application. Clearly, the modified Cam-clay model is inappropriate for modelling the behaviour of a weathered and compacted crust. It may be better modelled as an elastic layer rather than a 'soft' elastoplastic medium. An analysis of the case histories showed that the vacuum application via PVD substantially decreases lateral displacement, thereby reducing potential shear failure during rapid embankment construction.

There is no doubt that a system of vacuum-assisted consolidation via PVD is a useful and practical approach for accelerating radial consolidation. Such a system reduces the need for a high surcharge load, as long as air leaks can be eliminated in the field. Accurate modelling of vacuum preloading requires laboratory and field studies to investigate the exact nature of vacuum pressure distribution within a given soil formation and PVD system. In addition, a resilient system is required to prevent air leaks that can reduce the desirable negative pressure (suction), with time.

\section{NOTATION}

$a \quad$ width of band drain (m)

$B \quad$ equivalent half-width of the plane strain cell (m) 
$b \quad$ thickness of band drain (m)

$b_{\mathrm{s}} \quad$ equivalent half-width of smear zone in plane strain (m)

$b_{\mathrm{w}} \quad$ equivalent half-width of drain (well) in plane strain (m)

$c_{\mathrm{h}} \quad$ coefficient of horizontal consolidation $\left(\mathrm{m}^{2} / \mathrm{s}\right)$

$d_{\mathrm{e}} \quad$ diameter of effective influence zone of drain $(\mathrm{m})$

$d_{\mathrm{s}} \quad$ diameter of smear zone $(\mathrm{m})$

$d_{\mathrm{w}} \quad$ equivalent diameter of band drain $(\mathrm{m})$

$e_{0} \quad$ in situ void ratio

$k$ permeability $(\mathrm{m} / \mathrm{s})$

$k_{\mathrm{h}} \quad$ horizontal coefficient of permeability for axisymmetry in undisturbed zone $(\mathrm{m} / \mathrm{s})$

$k_{\mathrm{s}} \quad$ horizontal coefficient of permeability for axisymmetry in smear zone $(\mathrm{m} / \mathrm{s})$

$k_{\mathrm{hp}} \quad$ equivalent horizontal coefficient of permeability for plane strain in undisturbed zone $(\mathrm{m} / \mathrm{s})$

$k_{\mathrm{sp}} \quad$ equivalent horizontal coefficient of permeability for plane strain in smear zone $(\mathrm{m} / \mathrm{s})$

$k_{\text {wp }} \quad$ equivalent horizontal coefficient of permeability for plane strain discharge capacity $(\mathrm{m} / \mathrm{s})$

$k_{\mathrm{v}} \quad$ vertical coefficient of permeability $(\mathrm{m} / \mathrm{s})$

$k_{1} \quad$ vacuum reduction factor in the vertical direction

$l \quad$ length of drain $(\mathrm{m})$

$m_{\mathrm{v}} \quad$ coefficient of volume change $\left(\mathrm{m}^{2} / \mathrm{kN}\right)$

$n \quad$ spacing ratio $\left(=R / r_{\mathrm{w}}\right.$ or $\left.B / b_{\mathrm{w}}\right)$

$p_{0} \quad$ applied vacuum pressure at the top of drain $\left(\mathrm{kN} / \mathrm{m}^{2}\right)$

$p_{0 \mathrm{p}} \quad$ equivalent vacuum pressure used in plane strain analysis $\left(\mathrm{kN} / \mathrm{m}^{2}\right)$

$q_{\mathrm{w}} \quad$ discharge capacity for PVDs $\left(\mathrm{m}^{3} / \mathrm{s}\right)$

$R \quad$ radius of axisymmetric unit cell (m)

$r \quad$ radius $(\mathrm{m})$

$r_{\mathrm{s}} \quad$ radius of smear zone $(\mathrm{m})$

$r_{\mathrm{w}} \quad$ radius of vertical drain (well) $(\mathrm{m})$

$s \quad$ smear ratio $\left(=r_{\mathrm{s}} / r_{\mathrm{w}}\right.$ or $\left.b_{\mathrm{s}} / b_{\mathrm{w}}\right)$

$S \quad$ drain spacing $(\mathrm{m})$

$t \quad$ time (s)

$T_{\mathrm{h}} \quad$ time factor for horizontal drainage in axisymmetry

$T_{\mathrm{hp}} \quad$ time factor for horizontal drainage in plane strain

$T_{\mathrm{h}}^{*} \quad$ modified time factor for design chart

$U$ average degree of consolidation

$U_{\mathrm{r}} \quad$ average degree of radial consolidation

$U_{\mathrm{v}} \quad$ average degree of vertical consolidation

$\bar{u} \quad$ average excess pore pressure $(\mathrm{kPa})$

$\bar{u}_{0} \quad$ initial average excess pore water pressure $(\mathrm{kPa})$ 
VPR vacuum pressure ratio $\left(=p_{0} / \bar{u}_{0}\right)$

$x \quad$ distance from centreline for a unit cell (plane strain) (m)

$z \quad$ depth (thickness) of soil layer (m)

$\alpha \quad$ geometric parameter representing smear in plane strain

$\beta \quad$ geometric parameter representing smear in plane strain

$\theta \quad$ geometric parameter representing well resistance in plane strain

$\varepsilon \quad$ vertical strain

$\gamma \quad$ unit weight of soil or surcharge fill $\left(\mathrm{kN} / \mathrm{m}^{3}\right)$

$\gamma_{\mathrm{w}} \quad$ unit weight of water $\left(\mathrm{kN} / \mathrm{m}^{3}\right)$

$\lambda \quad$ slope of normally consolidated curve

$\kappa \quad$ slope of over-consolidated curve

$v \quad$ Poison's ratio

$\mu \quad$ Smear and well-resistance factor in axisymmetric

$\mu_{\mathrm{p}} \quad$ Smear and well-resistance factor in plane strain

\section{ACKNOWLEDGEMENT}

The authors gratefully appreciate the cooperation of the Airports Authority of Thailand (AAT), and also extend their thanks to the Asian Institute of Technology (AIT) for providing relevant field data reports.

\section{REFERENCES}

Asian Institute of Technology (1995) The Full-Scale Field Test of Prefabricated Vertical Drains for the Second Bangkok International Airport: Final report, Vol. 1, Asian Institute of Technology, Thailand.

Barron, R.A. (1948) The Influence of Drain Wells on the Consolidation of Fine-Grained Soils, Diss., US Eng. Office, Providence.

Chu, J., Yan, S.W. \& Yang, H. (2000) Soil improvement by the vacuum preloading method for an oil storage station, Geotechnique, 50(6), 625-632.

Cognon, J.M., Juran, I \& Thevanayagam, S. (1994) Vacuum Consolidation Technology- Principles and Field Experience, Proceedings of Conference on Vertical and Horizontal Deformations of Foundations and Embankments Deformations, College station, Texas.

Cooper M.R. \& Rose A.N. (1999) Stone column support for an embankment on deep alluvial soils, Proc. I. Civil Eng. Geotech. Eng., 137(1), 15-25.

Eriksson, U., Hansbo, S. \& Torstensson, B.A. (2000) Soil improvement at Stockholm-Armanda Airport, Ground Improv., 4, 73-80.

Gabr, M.A. \& Szabo, D.J. (1997) Prefabricated Vertical Drains Zone of Influence Under Vacuum in Clayey Soil, Proceedings of the Conference on In Situ Remediation of the Geoenvironment, ASCE, Minneapolis, Minnesota, 449-460.

Gao, C. (2004) Vacuum preloading method for improving soft soils of higher permeability, Ground Improv., 8(3),101-107. 
Hansbo, S. (1979) Consolidation of clay by band-shaped prefabricated drains, Ground Eng., 12(5), 16-25.

Hansbo, S. (1981) Consolidation of Fine-Grained Soils by Prefabricated Drains and Lime Column Installation, Proceedings of 10th International Conference on Soil Mechanics and Foundation Engineering, Balkema, Rotterdam, Vol 3, pp 677-682.

Hansbo, S. (1997) Aspects of vertical drain design: Darcian or non-Darcian flow, Geotechnique, 47(5), 983-992.

Hibbitt, Karlsson, \& Sorensen. (2004) ABAQUS/Standard User's Manual, Published by HKS Inc, Rhode Island.

Hird, C.C., Pyrah, I.C. \& Russel, D. (1992) Finite element modeling of vertical drains beneath embankments on soft ground, Geotechnique, 42(3), 499-511.

Holtan, G.W. (1965) Vacuum stabilization of subsoil beneath runway extension at Philadelphai International Airport, Proceedings of 6th ICSMFE, 2.

Holtz, R.D., Jamiolkowski, M.B., Lancellotta, R., \& Pedroni, R. (1991) Prefabricated Vertical Drains: Design and Performance, CIRIA, London, pp 1-131.

Indraratna, B. \& Redana, I.W. (1997) Plane strain modeling of smear effects associated with vertical drains, J. Geotech. Geoenviron. Eng., ASCE, 123(5), 474-478.

Indraratna, B. \& Redana, I.W. (2000) Numerical modeling of vertical drains with smear and well resistance installed in soft clay, Can. Geotech. J., 37, 133-145.

Indraratna, B. \& Rujikiatkamjorn, C. (2004) Mathematical Modeling and Field Evaluation of Embankment Stabilized with Vertical Drains Incorporating Vacuum Preloading, 5th International Conference on Case Histories in Geotechnical Engineering, University of Missouri-Rolla, New York, pp 2.05/1-2.05/8.

Indraratna, B. \& Sathananthan, I. (2003) Comparison of Field Measurements and Predicted Performance beneath Full Scale Embankments, Field Measurements in Geomechanics, FMGM. 2003, Oslo, Norway, Balkema, Rotterdam, pp 117-127.

Indraratna, B., Balasubramaniam, A.S., \& Balachandran, S. (1992) Performance of test embankment constructed to failure on soft marine clay, J. Geotech. Eng., ASCE, 118(1), 12-33.

Indraratna, B., Balasubramaniam, A.S., \& Ratnayake, P. (1994) Performance of embankment stabilized with vertical drains on soft clay, J. Geotech. Eng., ASCE, 120(2), 257-273.

Indraratna, B., Redana, I.W., \& Balasubramanium, A.S. (1999) Settlement Prediction of Embankments Stabilised with Prefabicated Vertical Drains at Second Bangkok International Airport, 12th European Conference on Soil Mechanics and Geotechnical Engineering for Transportation Infrastructure, ISSMGE, Balkema, Rotterdam, pp 1-7.

Indraratna, B., Redana, I., \& Bamunawita, C. (2003) Soft Ground Improvement by Vertical Drains, In-situ Soil Characterisation, Eds. Saxena, K.R. \& Sharma, V.R., Balkema, Rotterdam, Chap 9, pp 233-288.

Indraratna, B., Bamunawita, C. \& Khabbaz, H. (2004) Numerical modeling of vacuum preloading and field applications, Can. Geotech. J., 41, 1098-1110.

Indraratna, B., Sathananthan, I., Rujikiatkamjorn, C., \& Balasubramanium, A.S. (2005) Analytical and numerical modeling of soft soil stabilized by PVD incorporating vacuum preloading, Int. J. Geomech. 5, 114-124.

Kjellman, W. (1952) Consolidation of Clayey Soils by Atmospheric Pressure, Proceedings of a Conference on Soil Stabilization, Massachusetts Institute of Technology, Boston, pp. 258-263.

Mohamedelhassan, E. \& Shang, J.Q. (2002) Vacuum and surcharge combined one-dimensional consolidation of clay soils, Can. Geotech. J., 39, 1126-1138. 
Nicholson D.P. \& Jardine R.J. (1982) Performance of Vertical Drains at Queenborough Bypass, Vertical Drains, The Institution of Civil Engineers, London, pp 67-90.

Onoue, A. (1988) Consolidation by vertical drains taking well resistance and smear into consideration, J. Soils Found., 28(4), 165-174.

Qian, J.H., Zhao, W.B., Cheung, Y.K., \& Lee, P.K.K. (1992) The theory and practice of vacuum preloading, Compu. Geotech., 13, 103-118.

Richart, F.E. (1957) A review of the theories for sand drains, J. Soil Mech. Found. Div., ASCE, 83(3), $1-38$.

Roscoe, K.H. \& Burland, J.B. (1968) On the generalized stress strain behavior of wet clay, Engineering plasticity, Cambridge University Press, Cambridge, U.K., pp 535-609.

Sangmala, S. (1997) Efficiency of Drainage Systems of Vacuum Preloading with Surcharge on PVD Improved Soft Bangkok Clay, ME Thesis, Asian Institute of Technology, Bangkok, Thailand.

Saye, S.R. (2003) Assessment of Soil Disturbance by the Installation of Displacement Sand Drains and Prefabricated Vertical Drains, Geotechnical Special Publication No. 119, ASCE, Cambridge, MA, pp 325-362.

Shang, J.Q., Tang, M., \& Miao, Z. (1998) Vacuum preloading consolidation of reclaimed land: a case study, Can. Geotec. J., 35, 740-749.

Suvarnabhumi Airport. (2004) New Bangkok International Airport Co., Ltd, viewed 19 October 2004, http://www.bangkokairport.org/demo/en/location1en.php.

Tavenas, F., Mieussens, C. \& Bourges, F. (1979) Lateral displacements in clay foundations under embankments, Can. Geotech. J., 16, 532-550.

Yan, S.W. \& Chu, J. (2003) Soil improvement for a road using a vacuum preloading method, Ground Improvement, 7(4), 165-172.

Yoshikuni, H. \& Nakanodo, H. (1974) Consolidation of fine-grained soils by drain wells with finite permeability, Jpn. Soc. Soil Mech. Found. Eng., 14(2), 35-46. 
